\title{
Degree Resultatives as Second-Order Constructions
}

\author{
Jack Hoeksema \\ University of Groningen
}

\author{
Donna Jo Napoli \\ Swarthmore College
}

Resultatives in English and Dutch have developed special degree readings. These readings stem from a reinterpretation of the resultative predicate as indicating a high degree rather than an actual result. For example, when a parent says I love you to death, one need not call the cops, since the sentence is not about love turning lethal, but merely indicative of a high degree of affection. Such cases have often been noted in the literature as idiomatic, but this view ignores the fact that these are not isolated cases but productive constructions that can be used with a variety of verbs. We explore various resultative constructions in English and Dutch, and give a classification of the subtypes involved as well as their diachronic development from ordinary to degree interpretation. We link these subtypes to lexical semantic classes of verbs. Both English and Dutch show a steady growth in the lexical and structural diversity of degree resultatives throughout the early modern and contemporary periods (1600-2000). We focus in our paper on the period 1800-2000, for which we did an extensive corpus study using the Corpus of Historical American English (COHA) and Delpher (a collection of digitized Dutch newspapers, journals, magazines, and other resources). One of our findings is that, similar to other types of expressive language, such as degree modification and emphatic negation, taboo expressions play a role in degree resultatives; in fact, their role is excessive. We outline a number of the commonalities among the semantic domains of expressive language used in resultatives.

Keywords: grammaticalization, resultatives, intensifier, taboo, verb classes, corpus

\section{Introduction.}

There is a vast and still growing literature on resultatives. They play center stage in construction grammar (Goldberg 1995, chapter 8; Goldberg \& Jackendoff 2004) and related frameworks, such as Simpler Syntax (Culicover \& Jackendoff 2005, chapter 4, section 5) but also in lexicalist Montague grammar (Dowty 1979, chapter 2), LFG (Simpson 
1983), HPSG (Müller 2002, chapter 5), transformational grammar (Thompson 1973), Government and Binding Theory (Hoekstra 1988; Carrier \& Randall 1992; den Dikken 1995, chapters 2, 3, and 5), and Minimalism (Snyder 2001). The present study is a contribution to this body of work focused on a particular reading of certain resultatives. Our observations lead to similar conclusions, regardless of analytical framework.

The resultatives at issue here form a small but growing group of expressions with an intensifying function that are productive in a range of patterns. Henceforth, we refer to them as DEGREE RESULTATIVES. To see the difference between ordinary and degree resultatives, consider 1 .
(1) a. Jones wiped the dust off the book.
b. Smith beat the crap out of Jones.

Structurally, 1a and $1 \mathrm{~b}$ are alike (transitive, with a PP within the VP), but semantically they differ. In 1a, the resultative is literal: off the book is predicated of the direct object the dust and expresses the state that results from Jones's wiping action. In contrast, $1 \mathrm{~b}$ is not literally talking about Smith removing excrement from Jones' body, but about the intensity of the beating (Hoeksema \& Napoli 2008, Haik 2012, Perek 2016). That is, out of Jones is not predicated of the direct object the crap. The expression in $1 \mathrm{~b}$ is idiomatic, but it follows a productive pattern: One could substitute for beat verbs such as hit, bash, whack, kick, club, bludgeon, trample, clobber, and other verbs of contact-by-impact (Levin 1993) or verbs such as annoy, irritate, bug, and other psych verbs (Sells 1987). In such examples, the constructional contribution to the interpretation of the verb phrase is intensification (Gyselinck \& Colleman 2016a,b, Gyselinck 2018).

To account for resultatives such as in $1 \mathrm{~b}$, we introduce the concept of SECOND-ORDER CONSTRUCTIONS. Such constructions, at least initially, rely on corresponding first-order constructions for their interpretation (somewhat similar to secondary grammaticalization, as in Givón 1991, Traugott \& Trousdale 2013). That is, the degree interpretation of $1 \mathrm{~b}$ is available because the literal interpretation of $1 \mathrm{a}$ is available. Secondorder constructions, then, are derived from first-order constructions.

The emergence of second-order constructions is largely unpredictable: One cannot predict, in any given language, which first-order 
constructions would lead to second-order constructions. Yet it is possible to draw generalizations about particular (groups of) lexical items that appear in second-degree constructions. In case of degree resultatives, we demonstrate that they frequently involve taboo expressions referring to sex, defecation, bodily effluents, as well as various euphemisms. They also contain expressions describing death, disease, mental illness, and loss of body parts. However, which particular expressions are used in which constructions is largely arbitrary and language-specific, as our comparison of English and Dutch degree resultatives shows.

In a first-order construction, meaning is determined by the component lexical items, plus the constructional meaning contribution. In a second-order construction, the original constructional meaning is overwritten by a new interpretation, while the old interpretation, including the meaning of individual parts, is still potentially available, but far less readily. In $1 \mathrm{~b}$, the degree interpretation is the natural/salient one, but the literal, resultative interpretation is still accessible, though unlikely. Example 1b contains an ordinarily transitive verb, beat. The form verb $+[$ the + taboo term $]+$ out of $N P$ is an intensified variant of the form verb $+N P$, that is, beat Jones. In the former pattern, the expletive is the direct object; in the latter pattern, NP is the direct object; and in both, the NP Jones is the patient argument of the verb. Example $1 \mathrm{~b}$ in its literal, resultative reading belongs to the class of caused motion constructions: An agent causes an object to change location. However, in its second-order reading, it is an intensification of an action (beating) involving an agent and a patient.

Resultative predicates can also intensify the meaning of verbs that are typically intransitive:

(2) a. Jones was laughing himself sick.

b. Smith worked his ass off.

Example 2a has the form verb + reflexive $+X P$. The resultative predicate (here sick) often denotes death, dismemberment, sickness, and other taboo topics (on the intimate relation between taboo expressions, intensification, and pejoratives, see Napoli \& Hoeksema 2009). Example $2 \mathrm{~b}$, in contrast, has the form verb + possessive pronoun + body part + 
off (a somewhat productive pattern; Cappelle 2014). ${ }^{1}$ The possessive pronoun of $2 \mathrm{~b}$, like the reflexive of $2 \mathrm{a}$, is bound by the subject.

Resultative predicates that have a degree interpretation act as intensifiers. Dutch has various types of these intensifying degree resultatives. Some are very much like English-compare 3 to $2 \mathrm{a}$.

(3) Fred schrok zich dood.

Fred startled REFL dead

'Fred got startled out of his wits.'

Dutch also has intensifying degree resultatives that make reference to body parts, similar to English 2b, but with a reflexive instead of a possessive pronoun. About cases such as 3, Broekhuis et al. (2015:254) remark that "they mainly bring about an amplifying effect." They note that the same can be said about ditransitives such as in 4 , analyzed in Cappelle 2014. ${ }^{2}$

(4) a. Jaap schaamde zich de ogen uit de kop. Jaap shamed REFL the eyes out the head 'Jaap was ashamed to death.'

b. Ik pieker me een ongeluk.

I worry myself an accident 'I worry intensely.'

\footnotetext{
${ }^{1}$ As is clear from $2 b$, literal interpretations are often bizarre: $2 b$ is not about a mishap at work involving a chain saw. Importantly, $2 \mathrm{~b}$ is also not an instance of the African American Vernacular English (AAVE) camouflage construction discussed in Collins et al. 2008, where X's ass stands for a whole X exemplified in i.

(i) I'm gonna sue your ass.

Example i lacks the characteristic intensifier interpretation associated with degree resultatives. Contrast i with I'm gonna sue your ass off. The latter suggests that the addressee will be taken to the cleaners (so it is a degree resultative), whereas i merely threatens litigation. See also Irwin 2015 for discussion of AAVE attributive modifiers involving taboo body parts, such as Park your sorry ass car somewhere else, with related expressive meaning.

${ }^{2}$ The short form of the reflexive appears in $4 b$. For relevant discussion, see the remarks on Dutch type 1 in section 4.2.
} 
In 4, one finds two NPs within the VP, neither of which is inside a PP; this is the structural configuration we mean when we use the term ditransitive. Datives in the double object construction appear in this configuration as well. Some have argued, at least for English, that dative constructions form part of a larger set of constructions that includes resultatives (Snyder \& Stromswold 1997; but see Carrier \& Randall 1992, appendix). We do not, however, include datives in our discussion (whether in the double object construction or in PPs), because we have come across no examples of dative constructions that have a degree interpretation.

We treat ditransitives such as in 4 as a special case of resultatives. This analysis of 4 is coherent with the common view of resultatives, ditransitives, and directed motion constructions as all involving change along a (metaphorical) path (Simpson 1983, Hoekstra 1984, Larson 1988, Levin \& Rappaport Hovav 1991, Goldberg 1995, den Dikken 1995, Hale \& Keyser 1996). These three constructions cannot co-occur within a clause: In the same way that a resultative predicate cannot be added to a resultative construction that already contains a resultative predicate (apart from conjunction), it cannot be added to a ditransitive or directed motion construction, as shown in 5 (examples adapted from Goldberg 1995:82).

(5) a. He wiped the table dry (*clean).

b. Joe kicked Bob a suitcase (*open).

c. Sam tickled Chris off her chair (*silly).

Semantically, resultatives (including ditransitives) can often be analyzed as part of a complex construction containing a CAUSE predicate. ${ }^{3}$ For example, wipe the table clean means that the actor causes the table to become clean by wiping, while give someone a present means that the actor causes someone to have a present (Harley 2002). The same is true for caused motion: drive the truck to Atlanta means that the driver causes the truck to be in Atlanta (Dowty 1979). Resultatives discussed in this paper include these three types as subtypes. In each,

\footnotetext{
${ }^{3} \mathrm{We}$ are not claiming that all ditransitives are causative. For example, to begrudge someone something does not seem to have any causative entailments, just like verb $+N P+A P$ is not necessarily resultative, as in consider Jorge lazy, call Mariko stingy, find Hsing Hsing foolish.
} 
there is a caused result reinterpreted metaphorically as a gradable property indicating a high degree. ${ }^{4}$

Degree resultatives show a number of similarities with other types of intensifier expressions; they are quite common crosslinguistically and can be realized syntactically in various ways. In particular, English and Dutch degree resultatives follow several syntactic patterns. This syntactic variability suggests that emergence of second-order constructions is determined primarily not by the syntax but by the semantics. We point out two characteristics of the (literal) resultative constructions that license the (idiomatic) degree sense. Additionally, though English and Dutch are closely related languages, comparison of the two languages allows us to note subtleties of degree resultatives that might have gone unnoticed in a study of only one or the other of the languages. An

\footnotetext{
${ }^{4}$ One important aspect of this reinterpretation is that an actual change of state is not expressed. Whereas regular resultatives with atelic verbs such as Dutch martelen 'torture' are telic, the same is not true of degree resultatives. van Hout (2012:124) presents the following pair of examples, using a Dutch version of the well-known in an hour/for an hour-test (Dowty 1979), which marks predicates that combine with in an hour as telic and those that combine with for an hour as atelic.
}

(i) a. De dictator heeft de gevangene urenlang $/ *$ in een uur gemarteld. the dictator has the prisoner for hours / in an hour tortured 'The dictator tortured the prisoner for hours $/ *$ in an hour.'

b. De dictator heeft de gevangene in een uur /*urenlang the dictator has the prisoner in an hour / for hours doodgemarteld. dead-tortured

'The dictator has tortured the prisoner to death in an hour/*for hours.'

When one applies the same test to vervelen 'bore', there is no change in telicity:

(ii) Ik heb me urenlang $/ *$ in een uur (dood) verveeld. I have me for hours / in an hour (to death) bored 'I have bored myself to death for hours.'

This follows rather directly from the semantics of the degree resultative, since it does not express a change of state, but intensity. Zich doodvervelen 'be bored to death' is therefore atelic, just like zich vervelen 'be bored'. For discussion of telicity in the related area of particle verbs, see Walková 2017. 
examination of corpora from different time periods shows that the set of degree resultatives is rapidly expanding, due to the growing number of lexical items that can partake in the relevant constructions. The growth in the number of lexical items that can be interpreted as degree resultatives is analogous to the equally rapid growth in the number of lexical items that can be used as degree adverbs in Dutch in the period 1600-2000 (Hoeksema 2005). This is exactly what one might expect if the secondorder construction is semantically motivated; language embraces multiple ways to express intensity. The study here, then, sheds light on how second-order constructions can arise, diversify, and thrive.

The structure of the paper is as follows. Section 2 offers an account of why and how the term degree is used in this paper. Section 3 discusses the necessity of a gradable interpretation in order for a resultative predicate to be used as a degree expression. Section 4 categorizes the English and Dutch constructions in which degree resultatives occur and offers an account of how certain literal resultative interpretations lend themselves to metaphorical degree interpretations. Section 5 traces the historical development of degree resultatives over a 200 -year period in English and Dutch, noting the rise in number of types of constructions that can be interpreted as degree resultatives and in their frequency of use. Section 6 offers a semantic classification of the verbs that most frequently occur in degree resultatives. Section 7 notes other taboo or abusive terms that have yielded degree resultatives. Section 8 points out predictions of our account concerning DP versus PP complements of verbs. Section 9 is a conclusion.

\section{Two Words of Caution on the Notion of Degree.}

Why we apply the term degree to the second-order constructions discussed here calls for explanation, since for many, that term has taken on a particular formal meaning.

We suggest that there are various ways to express degree. In the literature on degree marking, much attention goes to adverbs of degree, and the morphosyntactically marked categories of comparatives and superlatives (Corver 1997, Neeleman et al. 2004). ${ }^{5}$ Degree marking, however, is not just a matter of lexical heads. A broader view of the issue

\footnotetext{
${ }^{5}$ At least in many European languages; other language families may use different strategies for marking comparatives and superlatives (see Stassen 1985).
} 
reveals important parallelisms between adverbs of degree and a number of other ways of expressing degree.

Suppose one wants to characterize Jones by ascribing to him a high degree of poverty. This could be done by using an adverb of degree: Jones is extremely poor, a stereotypical comparison: Jones is as poor as a church mouse, or a clause licensed by subordinating so that is read as a result of high degree: Jones is so poor that he has to send his children to the almshouse. One could also use pitch (and duration, see Braver et al. 2016): Jones is póór, or repetition: Jones is poor, poor, poor. Some languages also use a variety of morphological processes, such as affixation, including diminutives and augmentatives: Italian basta $e$ strabasta 'it's enough and it's more than enough', bello bellissimo 'beautiful very beautiful' (Dressler \& Merlini Barbaresi 1994). Spoken languages tend to have a high number of lexical contrasts (morphologically unrelated lexical items) indicating degree: English eat versus devour. A variety of means of intensification litters the components of the grammar, much more so than means of de-intensification (Zillig 1982, Polanyi 1985, Sandig 1991). Sign languages, in contrast, tend to indicate degree via changes in the phonological parameters (Wilcox \& Shaffer 2006) or via a separate degree sign (Brito 1984), although there are some lexical contrasts indicating degree, such as American Sign Language RAIN versus POUR.

There are also degree compounds (aka elative compounds), which are often comparison-based (German blitzschnell 'lightning fast') and may have a resultative meaning (Hoeksema 2012). Compare crystalclear lit. 'clear as crystal', that is, 'very clear' with Dutch stervenskoud lit. 'dying cold', that is, 'very cold'. In the latter, the interpretation does not seem to be 'as cold as dying', but 'so cold, that it might cause death'. Similar cases in Dutch are kotsmisselijk 'puke-nauseous', snotverkouden lit. 'snot suffering-from-a-cold', that is, to have a cold to the degree that it causes one to produce (lots of) snot, stomdronken lit. 'mute-drunk', that is, drunk to the extent one cannot talk anymore. The same contrast can be found in Italian, where degree compounds such as mondo cane 'dog world', donna cannone 'cannon woman/enormously fat woman', for example, seem to be solely comparative, but stanco morto 'dead tired' hints at a resultative sense.

In the light of this rich variety of ways of expressing degree, the second-order constructions examined in this paper are insightfully 
analyzed as examples of degree expressions. Thus, we step away from a narrowly construed treatment in terms of DegP's in favor of the older view (Sapir 1944, Bolinger 1972) of gradability and degree marking as a pervasive property of natural language, expressible by a variety of mechanisms.

Further, degree expressions have varying interpretations, though the nuances play no part in our overall discussion. Intensity or high degree is a variable notion. In the case of a verb such as sweat (I am sweating my guts out), one thinks of the amount of sweat produced. The same holds, mutatis mutandis, for other verbs of emitting effluents (puke, piss, bleed) and verbs of ingestion (eat, drink, gorge). In other cases, such as fight or sing, high degree is more about intensity than amount produced. In yet other cases, duration may come into play, as with wait (Dutch zich suf wachten 'wait oneself into a tizzy'). A verb like sleep (sleep one's ass off) may be interpreted equally well in terms of duration and intensity (depth of sleep). In addition, we include cases such as Dutch de sterren van de hemel zingen lit. 'sing the stars off heaven', that is, sing beautifully, where the high degree interpretation is arguably associated with the manner of singing rather than raw intensity, as might be the case with, say, Janis sang her guts out every night. In general, in many cases it would be hard to decide whether one is talking about the manner or the intensity of the rendering. We, thus, do not explore these distinctions here, instead lumping them all together as intensification, since the degree expressed by the resultative is always high.

\section{Degree Resultatives and the Importance of Endpoint.}

This paper looks at data from only English and Dutch. However, resultatives with varying syntactic structures occur in many spoken languages, including other Indo-European languages (French: Legendre 1997; German: Stiebels 1998; Romanian: Farkas 2011, as well as genetically unrelated languages (Chinese: Sybesma 1992, Cheng \& Huang 1995, Li 1995; Japanese: Washio 1997, Nishiyama 1998; Korean: Kim 1993, Wechsler \& Noh 2001; Thai: Matsui 2007; Yoruba: Baker 1989). None of these works mention degree resultatives, but it could be that the studies simply overlooked them, since their focus was elsewhere.

Sign languages also express resultatives in a number of ways (Loos 2017). A motion event that ends in a particular way, for example, might well involve one or more classifiers, with the endpoint of the motion 
having a phonological change iconic of the result in one or more of the classifiers (see Tang \& Yang 2007, Kentner 2014). For example, to state that a car hit a tree and that the tree fell over as a result, the classifier for 'car' might move toward the classifier for 'tree', hit it, and then the classifier for 'tree' might change orientation from upright to being on its side. Similarly, to state that the car hit a tree and that the car rumpled, one might begin the same way, but when one classifier hits the other, the classifier for 'car' which uses the 3-handshape (1/ ), might bend the extended digits ( $)$; if only the front of the car rumpled, the 3-handshape might bend only the extended index and middle fingers, and how tightly those fingers bend can indicate how great the rumpling was (SuttonSpence \& Napoli 2013). These resultatives can certainly be interpreted in an exaggerated and nonliteral sense, such as in a car hitting a tree so hard the tree flies up and flips a few times in the air before landing.

Sometimes these resultative degree interpretations can be encoded in single lexical items, such as the sign FALL-IN-LOVE in ASL, in which the dominant hand in a 1-handshape (like the classifier for person) literally falls on the palm of the nondominant hand and bounces along it. Several such signs appear in Irish Sign Language, including TONGUE-ROLL-OUTOF-MOUTH to indicate so good one drools, STEAM-COME-OUT-OF-EARS to indicate intense anger, EYES-POP-OUT-OF-HEAD to indicate astonishment, and HAIRS-STAND-UP-ON-ARM to indicate getting the creeps (Leeson \& Saeed 2012:134ff.). So far as we know, the first work to discuss this particular type of degree-resultative lexical items in sign languages was Wilcox et al. (2003:146), who said such items conveyed "deviant behavioural effect for intensity of experience" when talking about examples from ASL and Catalan Sign Language. In fact, even taboo degree resultatives occur in sign languages, as in ASL, such as NIPPLES-STIFFEN and BALLS-SHRINK to convey great cold, or GETERECTION to indicate attractiveness (Mirus et al. 2012).

Thus, our study may lead others to recognize degree resultatives in many languages, spoken and sign. Still, we predict that not all languages will have degree resultatives. Under our analysis, degree resultatives are second-order constructions that ride piggyback on ordinary resultatives (first-order constructions); they derive from ordinary resultatives and, therefore, cannot exist without them. Thus, if a language lacks literal resultatives, it will also lack intensifying degree resultatives, and if it has restrictions on literal resultatives, we expect those restrictions to hold for 
intensifying degree resultatives as well. The literature we have examined shows that this prediction holds cross-linguistically. That is, we have found no languages that have intensifying degree resultatives but no literal resultatives - an observation consistent with our claim that the former derive from the latter. However, we address an important complication regarding German in section 8.

Consider this prediction with respect to Italian. Italian exhibits a degree resultative exemplified in 6 with morire 'die' and impazzire 'go crazy' - two of the exceedingly few secondary predicates allowed in this construction.

(6) a. E' bella da morire.

is beautiful to die

'She is drop-dead gorgeous.'

b. Mi piace da impazzire!

me pleases to go-insane

'I like it a lot / I love it to pieces.'

The examples in 6 have a number of properties in common with a Dutch degree resultative construction exemplified in 7 (Heinsius 1929, Booij 2010).

(7) a. De professor herhaalde haar argumenten tot vervelens toe. the professor repeated her arguments to boring-GEN to 'The professor repeated her arguments ad nauseam.'

b. De jongen was tot gek wordens toe verliefd. the boy was too crazy become-GEN to in-love 'The boy was madly in love.'

On the whole, however, Italian lacks the variety of degree resultatives found in English and Dutch. Certainly, resultatives with reflexives and NPs denoting body-parts found in English and Dutch do not have counterparts in Italian. Our analysis of degree resultatives attributes this to the fact that Italian, and Romance in general, is impoverished with respect to secondary resultative predicates. In Romance, most secondary resultative predicates can occur only with endpoint-oriented or 
accomplishment verbs (see Napoli 1992 for Italian; Farkas 2009 for Romanian). Thus, it is no accident that only a few second-order resultatives can be interpreted as degree resultatives. Modern Greek patterns much like Italian or Spanish with regard to these restrictions on secondary resultative predicates (Giannakidou \& Merchant 1999), and, like Italian, has a degree resultative with 'to death' - a definite endpoint.

The notion of endpoint is an essential meaning component of secondary resultative predicates (under either literal or degree reading of the construction). However, in degree resultatives, what is important is not the endpoint itself, but the scale. Degree resultatives require gradable secondary predicates, which come in a variety of types (Kennedy \& McNally 2005). Some correspond to closed scales (with definite endpoints), some to open scales (without definite endpoints), and some to half-open scales (for example, the set of natural numbers $\mathbb{N}$ form a halfopen scale, with 1 as the definite endpoint at the lower end, but no upper endpoint). Depending on their scale type, different predicates combine with different modifiers (Klein 1998, Paradis 2001, Rotstein \& Winter 2004, Wechsler 2005). Closed-scale predicates easily combine with absolute modifiers (completely full, totally empty, absolutely dead), whereas open-scale predicates do not (*completely old, *totally large, *absolutely many), preferring nonabsolute modifiers (very, pretty, rather, quite). ${ }^{6}$

This notion of absolute modifier is not to be confused with the notion of maximality. Note that an absolute modifier does not necessarily trigger the endpoint interpretation of the predicate. For example, half marks a point on a scale; combined with a modifier it can yield an absolute modifier that does not denote the endpoint of the scale, such as half-blind (as in She sits there so refined, and drinks herself half-blind, from Barry Manilow's song "Copacabana"; the same is true for Dutch, as in 41 below).

The modifiers one finds most frequently with degree resultatives are of the absolute kind, even when the relevant predicate normally does not require an absolute modifier. For English, this point can be illustrated by the contrast between $8 \mathrm{a}, \mathrm{b}$, on the one hand, and $8 \mathrm{~b}, \mathrm{c}$ on the other.

\footnotetext{
${ }^{6}$ Note that the situation is more complicated than this outline suggests, witness expressions such as a little bit pregnant and, conversely, totally beautiful (Tribushinina \& Janssen 2011).
} 
(8) a. They drank themselves absolutely silly.

b. \#They drank themselves very/rather silly.

c. We consider them very silly.

Example 8a, with an absolute modifier, is entirely colloquial. Example $8 \mathrm{~b}$, with a nonabsolute modifier, sounds not entirely natural, perhaps self-conscious or humorous. We indicate this judgment here by \#. However, 8c, with a nonabsolute modifier, is entirely ordinary. That is, the felicity of the type of modifier depends not on the predicate itself (silly), but on the construction.

In Dutch, this same effect can be found and more easily, since a larger group of adjectives are employed with frequency in degree resultatives. In fact, the effect is so strong in Dutch that we debated using an * to indicate the acceptability judgments in $9 \mathrm{c}$ and $10 \mathrm{c}$, but opted instead for \#, to be consistent with how we treated the English examples. ${ }^{7}$

(9) a. Frits schrok zich lam.

Fritz startled REFL lame

'Fritz was startled out of his mind.'

b. Frits schrok zich helemaal lam.

Fritz startled REFL completely lame

'Fritz was startled completely out of his mind.'

c. \#Frits schrok zich erg lam.

Fritz startled REFL very lame

'Fritz was startled very much out of his mind.'

${ }^{7}$ Besides 'lame', as in 9, Dutch lam may also mean 'drunk/wasted', in which case it may take both absolute and nonabsolute degree modifiers:

(i) De studenten waren nogal/volkomen lam.

the students were rather/completely wasted

'The students were rather/completely wasted.'

The 'drunk' reading is potentially available in resultatives with the verbs drinken 'drink' and zuipen 'drink (heavily)':

(ii) We gaan ons lam drinken.

we go us wasted drink

'We are going to get wasted.' 
d. Het paard was een $\{$ beetje/erg $\}$ lam. the horse was a \{bit / very $\}$ lame 'The horse was a bit/very lame.'

(10) a. Gerda schaamde zich rot. Gerda shamed REFL rotten 'Gerda was ashamed to the core.'

b. Gerda schaamde zich helemaal rot. Gerda shamed REFL completely rotten 'Gerda was completely ashamed to the core.'

c. \#Gerda schaamde zich erg rot. Gerda shamed REFL very rotten 'Gerda was ashamed very much to the core.'

d. Gerda voelde zich erg rot. Gerda felt REFL very rotten 'Gerda felt very bad.'

Thus, the fact that rot in 10c does not readily combine with erg 'very' is not due to the lexical preferences of rot-since that would predict $10 \mathrm{~d}$ to be equally bad-but because it appears in a degree resultative. We conclude that the second-order construction itself imposes a scalar endpoint interpretation on the resultative predicate.

\section{Classification of Construction Types.}

Today degree resultatives in English and Dutch occur in several syntactic patterns. We outline and exemplify them here, both for ease of reference in our later discussion of their emergence over time and in order to give a sense of the range of data behind the tables in that later discussion.

\subsection{English.}

We outline six syntactic patterns of degree resultatives; then we summarize them in a table. The first syntactic pattern in English (type 1) is verb + fake reflexive + predicate. The meaning of the following types of verbs can be intensified by adding a reflexive pronoun and a resultative predicate: Intransitive verbs (such as laugh), optionally 
transitive verbs (such as eat), and verbs that can have a causative interpretation when used transitively (such as jump). The added resultative predicate provides a scalar endpoint. It typically has a negative connotation, denoting a state such a death, sickness, decay, etc., as in $2 \mathrm{a}$ above. This state, understood metaphorically, specifies an (end)point on a scale (as discussed in section 3). The resultative construction as a whole, however, does not necessarily have a negative connotation. For example, sick is a negatively evaluated state, but laughing oneself sick involves maximal mirth without adverse associations. In other cases, such as working oneself to death, there is a finer line between a literal interpretation and a merely intensifying interpretation. Still, one can say Every week, I work myself to death, and I love it. The modifier every week makes it clear that no literal reading is intended, while the second conjunct indicates a positive appraisal. Among the most common verbs that appear with this kind of intensification are laugh, dance, work, drink, and eat. The resultative predicate may be an AP (laugh oneself sick) or a PP (drink oneself to death). There may be restrictions on which verb combines with which predicate, as discussed in the next section.

The reflexive in this type of resultative construction is fake (Simpson 1983) because either the verb does not subcategorize for an object, or the object does not satisfy the verb's usual selectional restrictions. For example, sing is usually intransitive, although it can take objects that are within its referential extension, such as a song or the national anthem. In particular, it does not generally allow an animate object, yet in sing oneself hoarse, the object is [+animate]. Fake reflexives cannot bear contrastive stress, a characteristic that helps in identifying them:

\section{(11) *I am only laughing MYSELF sick.}

The second syntactic pattern in English (type 2) is verb $+X$ 's body part $+\{$ off $/$ out $\}$. This construction also contains mostly intransitive or optionally transitive verbs. The NP that denotes the body part does not satisfy the verb's selectional requirements; thus, it is not a genuine argument but rather a fake object (extending the use of the term fake reflexive). The verbs cry, freeze, fuck, laugh, scream, and work are commonly used in combinations such as freeze X's extremities off, cry $X$ 's eyes out, scream $X$ 's head off, and work $X$ 's tail off. Often the 
possessive pronoun is bound by the subject, as in 12 , whereas other times, the possessive may be free, as in 13 .

(12) a. We were freezing $\{$ our $/ *$ their $\}$ balls off.

b. The baby was crying $\{$ his $/ *$ my $\}$ eyes out.

c. The kids were screaming $\{$ their/*your $\}$ heads off.

(13) a. The visitor was talking my ears off.

b. They kept on blabbering her ears off.

c. You're working our balls off, do you realize that?

With verbs of communication (understood broadly enough to include sing) that take a goal/beneficiary argument, a free possessive pronoun is understood to be that argument.

(14) a. Please sing to me. Go on, sing my ears off.

b. Don't blabber to us. You're blabbering our ears off.

When the possessives are bound, they require local antecedents just as fake reflexives do, as in 15a; they reject the use of own, as in $15 \mathrm{~b}$, as well as any form of contrastive stress, as in $15 \mathrm{c}$.

(15) a. *We thought they were crying our eyes out.

b. *Freddy was crying his own eyes out.

c. *Freddy was crying HIS eyes out.

The third syntactic pattern in English (type 3) is verb $+[$ the + taboo term] $+[$ out of $N P]$. This type of construction nearly always involves verbs that require a direct object. Examples include expletives, such as scare the hell out of someone, annoy the shit out of someone, beat the living crap out of someone, etc., as well as milder taboo terms that a parent, for example, might not be upset if a child used, such as those having to do with death or religion, including scare the living daylights out of someone, beat the devil out of someone. As noted earlier, however, while the expletive is the direct object of the verb, it is not an argument, nor does it satisfy the verb's usual selectional restrictions. Thus, once again, one is dealing with a fake object. The argument-patient in this case- is the NP in the PP [out of NP]. 
Sometimes, this construction may contain a verb that usually does not take a direct object; instead, it takes a PP where the object of $\mathrm{P}$ is an argument of the verb. A blog post by Zimmer (2016) and Perek (2016) note relevant cases, such as 16 , involving listen to, from COCA (Corpus of Contemporary American English). In 16, what would have been the object of to in the absence of a fake object (that is, your tape, as in listen to your tape) appears as the object of out of. ${ }^{8}$

(16) Six months later Joe Perry called him and said: 'I've been listening the hell out of your tape. Let's do something.'

The fourth syntactic pattern in English (type 4) is verb $+N P+$ predicate. Very often this is an ordinary transitive construction with a resultative secondary predicate added, as in love someone to death, bore someone stiff, scare somebody shitless. It has a passive counterpart (compare $17 \mathrm{a}-\mathrm{c}$ with $17 \mathrm{~d}-\mathrm{e}$, ungrammatical passive sentences corresponding to type 3 ).

(17) a. We were scared witless.

b. Your parents must be worried sick.

c. The boys were bored stiff.

d. *Fred was annoyed the crap out of.

e. *The crap was annoyed out of Fred.

Just as with English type 1, sometimes this construction contains an object that does not satisfy the selectional restrictions of the verb, and, in that sense, is fake; thus, the resultative predicate licenses a fake object. Furthermore, sometimes one finds verbs that can be understood as causative when they have an object (for example, work in They worked us too hard). In fact, the same range of verbs that allow a fake reflexive in English type 1 also appear in English type 4 with a fake object. Interestingly, even these English type 4 examples have passive counterparts, as shown in 18 (though sometimes the get-passive sounds distinctly better than the be-passive).

\footnotetext{
${ }^{8}$ Note that listen may have a direct object in the particle verb construction listen out, as in please, listen us out.
} 
(18) a. They worked us to the bone. / We were worked to the bone.

b. I danced her dizzy. / She was danced dizzy.

c. Our teenage daughter drank us under the table. / We got drunk under the table by our teenage daughter.

d. He'll eat you out of house and home. / You'll get eaten out of house and home.

e. She laughed him out of the room. / He was laughed out of the room.

This raises the question of whether English type 1 really should be separated from English type 4. We demonstrate an advantage to maintaining this distinction when we turn to Dutch later. In the active sentences in 18 , the syntactically complex structure (subject, primary verb, fake object, resultative predicate) gives rise to different interpretations of who is doing the action. In some instances, the subject is understood to have caused the object to do the primary action (as with 18a). In others, the subject is understood to have done the primary action plus caused the object to do that action (as with 18b). Still in others, the subject and object are both understood to have done the action, but the subject "out-does" the object (as with 18c, similar to She outdrank us). Finally, the subject can be understood to have done the action with a resultant negative effect on the object (as in $18 \mathrm{~d}-\mathrm{e}$ ).

Also, just as with English type 3, sometimes this construction contains a verb that usually does not take a direct object, but, instead, takes a PP where the object of $\mathrm{P}$ is an argument of the verb. That argument winds up promoted to direct object position, as in 19.

(19) A: We need to talk about this.

B: Sure. But we don't need to talk it to death.

The next syntactic pattern (type 5) is verb $+N P+[$ out of X's body part]. This is also an ordinary transitive construction with a resultative secondary predicate. NPs that denote body parts and associated concepts range over brain, wits, mind, skin, skull, etc., and the possessive must be bound by the experiencer argument of the verb, as shown in 20 . 
(20) a. [The sheriff] $]_{i}$ scared herj out of $\left\{*{ }^{*} \mathrm{his}_{\mathrm{i}} / \mathrm{her}_{\mathrm{j}}\right\}$ wits.

b. [The lecture $]_{i}$ bored them ${ }_{j}$ out of $\left\{*_{i} \mathrm{its}_{\mathrm{i}} /\right.$ their $\left._{\mathrm{j}}\right\}$ skull.

c. [Thunder claps] $]_{i}$ will frighten Fido out of $\left\{{ }^{*}\right.$ their $_{i} /$ his $\left._{j}\right\}$ senses.

d. Norai irritates mej $_{j}$ out of $\left\{{ }^{*} h^{2} r_{i} / m_{j}\right\}$ mind.

We distinguish English type 5 from English type 4 because its passive counterpart is more common than the active construction.

The next syntactic pattern (type 6) is verb + the \{clothing/body part $\}$ $+[$ off $N P]$. This construction has a transitive verb whose object denotes a piece of clothing or a body part, but that object is fake. The genuine argument of the verb - experiencer in this case - is the NP object of the preposition off (\{charm/annoy/scare $\}$ the pants off somebody). An example from our corpora is provided in 21.

(21) I think we could bore the pants off the viewers if we did something of that kind. ${ }^{9}$

We show in section 6.4 that the examples with clothing differ from the examples with body parts in certain ways. Therefore, we talk about English type 6a, which concerns clothing, and English type 6b, which concerns body parts.

In table 1, we present the six types of degree resultatives we have characterized above.

\begin{tabular}{|c|l|l|}
\hline Type & Structure & Example \\
\hline 1 & verb + fake reflexive + predicate & laugh oneself silly \\
\hline 2 & verb + X's body part $+\{$ off $/$ out $\}$ & scream one's head off \\
\hline 3 & verb $+[$ the + taboo term $]+[$ out of NP] $]$ & annoy the hell out of someone \\
\hline 4 & verb + NP + predicate & $\begin{array}{l}\text { love someone to death } / \\
\text { bore someone stiff }\end{array}$ \\
\hline 5 & verb + NP $+[$ out of X's body part $]$ & bore people out of their skull \\
\hline $6 \mathrm{a}$ & verb + the clothing $+[$ off $\mathrm{NP}]$ & charm the socks off someone \\
\hline $6 \mathrm{~b}$ & verb + the body part $+[$ off $\mathrm{NP}]$ & nag the ears off someone \\
\hline
\end{tabular}

Table 1. Six types of degree resultatives in English.

\footnotetext{
${ }^{9}$ Ronald Reagan's reaction to Walter Mondale's suggestion that they should have a dozen or so TV debates for the 1984 presidential elections.
} 
In sum, English presents six distinct constructions that degree resultative phrases occur in, where four of them contain a reflexive or body part/clothing bound by an argument of the verb. We consider this distribution in section 4.3 below.

\subsection{Dutch.}

We outline four patterns of degree resultatives in Dutch, then summarize them in a table. However, before listing and exemplifying the types, we need to explain that Dutch word order generally places the finite verb in verb-second position and places other forms (perfect or passive participles, for example) at the end of the VP. For the sake of simplicity of exposition, we characterize our construction types in terms of the verb being at the end of the VP, since that is where the main verb will be if auxiliaries are used. Please keep that in mind when comparing the examples to the type pattern.

The first syntactic pattern in Dutch (type 1) is fake reflexive + predicate + verb. The examples in 22 contain fake reflexives with resultative predicates in a structure that looks identical to English type 1.

(22) a. We schaamden ons dood. we shamed ourselves dead 'We were ashamed to death.'

b. Ik erger me kapot. I annoy myself kaput 'I am annoyed as hell.'

c. De boeren werkten zich krom. the farmers worked REFL bent 'The farmers worked their asses off.'

d. De studenten verveelden zich rot. the students bored REFL rotten 'The students were bored stiff.'

There is an important difference between the English and Dutch instances of type 1 , however. The Dutch cases typically employ what is known as the short forms of the reflexive, for example, zich 
'him/her/itself' rather than the long form zichzelf. This has to do with the fact that the reflexive is inherent in these constructions: The verb cannot take an object that is distinct in reference from the subject. Inherent reflexives in Dutch are generally short forms (but see discussion in Hendriks et al. 2014). This is the reason why we did not conflate English type 1 with English type 4 in our discussion of English above; maintaining the distinction facilitates comparison of the two languages.

Dutch uses the short forms of inherent reflexives (Everaert 1986, Reinhart \& Reuland 1993, Bouma \& Spenader 2008), but it appears that the complementary distribution of short and long reflexives described in the linguistic literature is showing signs of weakening. New usage of long reflexives is attested on the online social network Twitter, where they creep, albeit still rarely, into inherent-reflexive positions. ${ }^{10}$ The long forms cannot be interpreted contrastively in their innovative use as fake reflexives, whereas they can be in their other uses. In 23a, a fake reflexive of Dutch type 1 appears in the nonstandard long form mezelf, where mezelf cannot bear contrastive stress (whereas dood 'dead' can, as indicated). In 23b, an ordinary transitive resultative of Dutch type 4 (discussed below and comparable to English type 4 discussed above) contains the expected long form mezelf, which can bear contrastive stress (as indicated).
a. Ik schrok mezelf/\#MEZELF dood/DOOD.
I startled myself dead
'I startled myself dead.'

${ }^{10}$ A referee suggested we use a fixed corpus such as NL-COW here. However,
this corpus is both a bit small and too well-written to exhibit many nonstandard
forms, at least among reflexives. Twitter, however, is ideal for nonstandard
language. From 2014 Twitter we have the following data on two verbs (selected
at random): vervelen 'bore' and ergeren 'annoy'.
(i) a. Ik verveel me dood (I bore self dead='I am bored to death') 14023 Tweets
b. Ik verveel mezelf dood (nonstandard, with long reflexive) 2 Tweets
(ii) a. Ik erger me dood (I annoy self dead='I am annoyed to death') 1888 Tweets
b. Ik erger mezelf dood (nonstandard, with long reflexive)

This distribution amounts to roughly 1 in 5,000. Thus, the nonstandard form (often routinely starred by linguists) is attested and used by some. 
b. Ik schiet liever MEZELF dood.

I shoot rather myself dead

'I would rather shoot myself dead.'

The second syntactic pattern in Dutch (type 2) is (possessive) body part $_{1}+[\{$ uit 'out'/op 'on' $\} X$ 's body part 2$]+$ verb. In 24, Dutch examples of this construction have many similarities to the English construction of type 2. The direct object in Dutch, however, can denote either a body part (as in 24a, the eyes) or a sign of degradation or distress (that is, affliction) of a body part (as in $24 \mathrm{~d}$, the blisters). The object of the preposition (uit 'out' or op 'on') denotes another body part and is preceded by a possessive pronoun. However, only those direct objects that denote actual body parts can appear with an overt possessive (Cappelle 2014). In 24a-c, the direct object appears without a possessive; the version with a possessive - comparable to English - is given in square brackets. Note that $24 \mathrm{~d}-\mathrm{-e}$ involve affliction of a body part, hence there is no example with a possessive on the direct object.

(24) a. Jullie moeten de ogen uit je kop schamen. you.PL should the eyes out your head shame 'You guys should be ashamed to death.'

[Jullie moeten je ogen uit je kop schamen. you.PL should your eyes out your head shame]

b. Callas zong de longen uit haar lijf.

Callas sang the lungs out her body

'Callas sang her heart out.'

[Callas zong haar longen uit haar lijf.

Callas sang her lungs out of her body]

c. Dirk Kuyt rende de benen uit zijn lijf.

Dirk Kuyt ran the legs out his body

'Dirk Kuyt ran himself ragged.'

[Dirk Kuyt rende zijn benen uit zijn lijf.

Dirk Kuyt ran his legs out of his body] 
d. De advocaat praatte de blaren op zijn tong. the solicitor talked the blisters on his tongue 'The solicitor talked his head off.'

e. Hij fietste zich het snot voor de / zijn ogen he biked REFL the snot before the / his eyes 'He rode his bicycle as fast as he could'

If true body parts appear as both the direct object and object of the preposition, they must be semantically related: The first body part (the direct object) is typically a meronym of the second body part (the object of the preposition; we include lijf 'body' in 24c). That is, the first denotes a part of the second.

The idioms in 25 have variants in which the possessor is expressed by a short reflexive pronoun. In these instances, instead of the possessive pronoun, the object of the preposition (that is, body part 2 ) appears with the definite article. ${ }^{11}$

(25) Callas zong zich de longen uit het lijf. Callas sang REFL the lungs out the body 'Callas sang her heart out.'

Perhaps this is because the possessive pronouns in examples such as 25 are locally bound by the subject. Indeed, local binding is required, as shown in 26.

(26) a. Kuyt $\mathrm{j}_{\mathrm{j}}$ zag dat Van Persie ${ }_{i}$ de benen uit zijn $_{\mathrm{i} / *_{j}}$ lijf liep. Kuyt $_{j}$ saw that Van Persie $i_{i}$ the legs out his ${ }_{i / *_{j}}$ body ran 'Kuyt saw that Van Persie ran himself ragged.'

[Kuyt zag dat Van Persie ${ }_{i}$ zijn $_{i} *_{j}$ benen uit zijn $_{i} *_{j}$ lijf liep. Kuyt saw that Van Persie his ${ }_{i} *{ }_{j}$ legs out his ${ }_{i} / *_{j}$ body ran]

\footnotetext{
${ }^{11}$ In rare cases, the PP contains both a reflexive and a possessive pronoun. The choice between the various kinds of possessor markings in these idioms differs on a case by case basis and is not stable diachronically (Bouma 2016).
} 
b. De advocaat praatte de blaren op $\{$ zijn/*mijn $\}$ tong. the solicitor talked the blisters on $\left\{\right.$ his $/{ }^{*}$ my $\}$ tongue 'The solicitor talked $\{$ his/*my\} head off.'

The construction requires coreference, in one instance with a possessive and in the other with a reflexive. This is not uncommon; in many languages reflexives appear instead of possessives with inalienable objects (Herschensohn 1992, Postma 1997, Lødrup 1999).

As expected and just like the English cases cited above, the possessive in examples such as 24 cannot be strengthened by eigen 'own', nor can it bear contrastive stress. Further, the reflexive in examples such as 25 cannot bear contrastive stress, nor can it be replaced with the long-form reflexive (but note the proviso mentioned above). Contrast $24 \mathrm{a}, \mathrm{b}$ to $27 \mathrm{a}, \mathrm{b}$, and 25 to $27 \mathrm{c}$.

a. *Jullie moeten de ogen uit je eigen kop schamen. you.PL must the eyes out your own head shame 'You should be ashamed to death.'

b. *Callas zong de longen uit HAAR lijf. Callas sang the lungs out her body 'Callas sang her heart out.'

c. *Callas zong zichzelf de longen uit het lijf. Callas sang REFL the lungs out the body 'Callas sang her heart out.'

The construction in 25, then, is ditransitive, where both objects (the

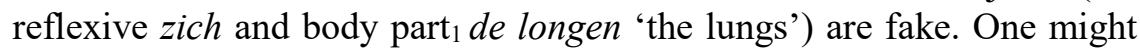
well want to categorize this construction as Dutch type $2 \mathrm{~b}$ : reflexive + body part $_{1}+[\{$ uit/op $\}$ Def Art body part 2$]+$ verb.

Quite generally, Dutch type 2 (including Dutch type $2 b$ ) does not occur with verbs that usually link an argument to direct object position (genuinely transitive verbs); and all the direct objects in this construction discussed so far have been fake. Given that, one does not expect to find arguments in direct object position in Dutch type 2. However, a few verbs of communication are exceptional (such verbs appear in English type 2, but their behavior is different in Dutch). In 28a, the object of the 
preposition, Annie, is the goal argument of the communication verb praten 'talk'. This verb occurs in a degree resultative in $28 \mathrm{~b}$, where the goal argument has been promoted to direct object of the verb. Given that body part ${ }_{1}$ is present as well (de oren 'the ears'), 28b is a ditransitive construction, where the first object is an argument of the verb (the goal) and the second one is not. As in the ditransitive construction in 25, which has a reflexive, in $28 \mathrm{~b}$ body part 2 (het hoofd 'the head') is introduced by a definite article rather than a possessive; both body parts are understood to belong to Annie (the first object, still the goal argument of the verb).

(28) a. Marie praat met Annie.

Marie talks to/with Annie

'Marie talks to Annie'

b. Marie praat Annie de oren van het hoofd.

Marie talks Annie the ears off the head

'Marie talks Annie's ears off.'

Other communication verbs exhibit somewhat different behavior. Example 29a contains the verb vragen 'ask', which can occur with an argument in direct object position and another argument as the object of the preposition. Just as with praten above, the object of $\mathrm{P}$ is the goal argument. In 29b, vragen occurs in a degree resultative, but the goal argument has been promoted to direct object (as in 28b).

(29) a. Marie vraagt de tijd aan Annie.

Marie asks the time to Annie

'Marie asks Annie the time.'

b. Marie vraagt Annie het hemd van het lijf.

Marie asks Annie the shirt off the body

'Marie is asking Annie's head off.'

At this point we need to recognize the construction Dutch type 2c: $N P+$ Def Art body part $_{1}+[\{$ van $\}$ Def Art body part 2$]+v e r b$. Thus, Dutch type 2 has three instantiations, with two of them being ditransitives. We have analyzed them as instances of one type of construction for two reasons. First, there are two body parts in all of them, with the first one being a meronym of the second. Second, the 
body parts are understood to belong to an individual expressed as an argument of the verb. The three subtypes of Dutch type 2 can be conflated formally as follows: $(\{N P /$ reflexive $\})+\left\{\left(X^{\prime} s\right) /\right.$ Def Art $\}$ body part $_{1}+[\{$ uit/op/van $\}\{X$ 's/ Def Art $\}$ body part $]+$ verb.

The next syntactic pattern in Dutch (type 3 ) is $\{$ fake reflexive $/ N P\}+$ $N P+v e r b$. This construction is not a structural counterpart to English type 3. In fact, Dutch has no structural counterpart to English type 3 and English has no structural counterpart to Dutch Type 3. However, the Dutch and English type 3 constructions do have in common the fact that a taboo item often appears in both (such a term referring to a disease).

Dutch type 3 with a fake reflexive looks very much like Dutch type 1 , especially given that the NP result is, arguably, a predicate (see remarks on a variety of NP predicate types in resultatives as well as copular and other constructions in Hoekstra \& Mulder 1990, Fernández Leborans 1999:2359-2365, Müller 2002, chapter 5, Bentley 2017). However, we argue that the construction with a fake reflexive and the one with a referential NP should be grouped together under type 3 for two reasons. First, when there is a fake reflexive in Dutch type 3, the phrase following it is always an NP that denotes an unpleasant result for the subject, such as a bump on the head, a horrible disease, or an accident. Consider the examples in 30.

(30) a. Het publiek schrok zich een ongeluk. the audience startled REFL an accident 'The audience was startled witless.'

b. We werken ons de tyfus. we work REFL the typhus 'We work our tails off.'

c. Mies twittert zich een beroerte.

Mies tweets REFL a stroke

'Mies tweets her ass off.'

In $30 \mathrm{a}$, the audience is startled as though they have had an accident; in $30 \mathrm{~b}$, the subject we can be seen as left suffering from typhus; in 30c, Mies might end up giving herself a stroke. As in other degree resultatives, none of these result phrases are to be taken literally; they are 
meant to indicate high intensity. Thus, there is no possibility for a counterpart to any of the examples in 30 with a long reflexive form and/or contrastive stress that would receive a literal reading (that is, there are no sentences comparable to 23b).

A second reason to keep Dutch type 3 with a fake reflexive separate from Dutch type 1 is its resistance to being compositional semantically. At times the NP that co-occurs with the reflexive takes on a special meaning, making the construction an idiom (as in 31a). Other times the NP does not occur outside this particular construction type; that is, it is a "cranberry word" (see Trawiński et al. 2008), for which a proper meaning is (nearly) impossible to give (as in $31 \mathrm{~b}, \mathrm{c}$ ).

(31) a. Hij schrok zich een hoedje.

he startled REFL a hat-DIM

'He was startled out of his mind.'

b. Hij werkt zich het schompes.

he works REFL the schompes

'He works his tail off.'

c. Zij werkt zich de rambam.

she works REFL the rambam

'She works her ass off.'

Nobody seems to know (including the main dictionaries of Dutch) what schompes or rambam mean, apart from the fact that they are assumed to be the names of imaginary diseases; startling oneself "a little hat" is not easy to explain either. ${ }^{12}$

In some instances it seems that analogy with another expression lies at the source of examples like those in 31 . To see what we mean, consider another example of an idiomatic intensifying degree resultative: zich een rotje schrikken lit. 'oneself a firecracker startle' = 'startle heavily'. The word rotje 'firecracker' makes no literal sense in this context. However, there is a common idiom zich rot schrikken 'startle oneself rotten' and another common one zich een hoedje schrikken

\footnotetext{
${ }^{12}$ It has been suggested that rambam has a Yiddish origin, deriving from the acronym of the rabbi Maimonides (Endt \& Frerichs 1986), but this suggestion, even if true, hardly helps in understanding the idiom.
} 
'startle oneself out of one's mind' (seen in 31a above). Zich een rotje schrikken may have emerged as a contamination of these two idioms.

In both examples in 30 and in more idiomatic ones as in 31 , the NP is headed by the indefinite singular article een, except when the NP denotes a disease (or quasi-disease), in which case the article is singular and definite (het for neuter nouns; de for singular nouns, where masculine and feminine are conflated).

One also finds degree resultatives that fit the pattern of Dutch type 3 but with a fully referential NP instead of a fake reflexive. This NP is an ordinary direct object of the verb, receiving a theta-role, as in 32 . We analyze the constructions in 32 as examples of Dutch type 3 because the second NP within the VP still indicates an unpleasant result for the subject within the same range of unpleasant results. Unlike 32a,b, the example in $32 \mathrm{c}$ contains not a disease name but a taboo term, de moeder 'the mother', a recent innovation in informal Dutch. It is not in our Delpher data, but attested on the Internet from 2010 onward.

(32) a. Ze hebben die jongen de tering geslagen. they have that boy the tuberculosis hit 'They beat the hell out of that boy.'

b. Ik schop je de tyfus.

I kick you the typhus

'I will kick you senseless.'

c. Sylvana gaat jullie de moeder slopen.

Sylvana goes you the mother demolish

'Sylvana is going to demolish the hell out of you.'

(PowNed, posted on YouTube on May 31, 2016)

The next syntactic pattern in Dutch (type 4) is $N P+$ predicate + verb. This type is very much like English type 4, as seen in 33 .

(33) a. De zeelui schopten de verstekeling verrot. the sailors kicked the stowaway rotten 'The sailors kicked the living shit out of the stowaway.'

b. Mijn vader sloeg me vaak helemaal verrot. my father beat me often completely rotten 'My father often beat the tarnation out of me.' 
The examples in 33 have verbs of contact-by-impact (just like the Dutch type 3 examples in 32). The particular examples in 33 were chosen specifically to illustrate a degree reading. For other combinations of predicate + verb, such as kapot slaan lit. 'kaput hit', there is ambiguity between a literal reading of 'hit something causing it to become broken' and a degree reading of 'hit something hard'. Both English and Dutch make copious use of contact-by-impact verbs in type 4 constructions.

The object in examples such as 33 is an argument of the verb, and the sentences are grammatical with or without the degree resultative. However, just as happens with English type 4, there are some Dutch verbs that generally do not take an object; yet, in combination with a resultative predicate, an object is licensed, so an object can occur in Dutch type 4 (compare English examples in 18). The resultative predicate in such instances can be a simple particle (such as uit 'out') or a degree resultative phrase. The examples in 34 contain schelden 'swear, call names, scold', which does not take a direct object except when it cooccurs with a resultative phrase.

(34) a. De sergeant schold. the sergeant cursed 'The sergeant cursed.'

b. De sergeant schold de soldaat*(uit). the sergeant cursed the soldier out 'The sergeant cursed the soldier out.'

c. De sergeant schold de soldaat *(verrot). the sergeant scolded the soldier rotten 'The sergeant cursed the soldier's head off.'

d. De sergeant schold de soldaat*(de huid vol). the sergeant scolded the soldier the skin full 'The sergeant cursed the soldier's head off.'

The Dutch construction does differ in some ways from the English one, however. For example, English freely uses many psych verbs in type 4 (as in annoy someone to death), but Dutch has limitations on psych verbs. Consider the verb ergeren 'annoy'. This verb can be used as 
a simple transitive, as in 35a, where the experiencer is the direct object. However, unlike in English, a degree resultative phrase cannot be added, as shown in $35 \mathrm{~b}$.

(35) a. Annie ergert Marie.

Annie annoys Marie

'Annie annoys Marie.'

b. *Annie ergert Marie groen en geel. Annie annoys Marie green and yellow

'Annie annoys Marie to the bone.'

Alternatively, ergeren can be used with a fake reflexive (the short form only, which cannot receive contrastive stress), where the experiencer is the subject and the entity causing the annoyance is the object of $\mathrm{P}$, as in 36 .

(36) Marie ergert zich aan Annie.

Marie annoys REFL to Annie

'Marie is/gets annoyed at Annie.'

To this structure, a degree resultative phrase can be added, so in contrast to $35 \mathrm{~b}, 37 \mathrm{a}$ is grammatical, again with the idiom groen en geel. Example $37 \mathrm{~b}$, which is ambiguous between a degree and literal reading, is grammatical as well.

(37) a. Marie ergert zich groen en geel aan Annie. Marie annoys REFL green and yellow to Annie 'Annie annoys the hell out of Marie.'

b. Marie ergert zich dood aan haar. Marie annoys REFL dead to her 'Marie is annoyed to death by her.'

Here $\{$ groen en geel/ dood $\}$ is predicated of the fake reflexive and thus, per force, of the subject. Thus, the structures in 36 and 37 can be seen as a variant of type 4 . We refer to the first one as Dutch type $4 \mathrm{a}$ and to this one as Dutch type $4 \mathrm{~b}$ : fake reflexive + predicate $+[P+N P]+$ verb. 
For the vast majority of speakers, psych verbs such as shockeren 'shock', storen 'bother, disturb', irriteren 'irritate' are acceptable only in simple transitive constructions (as in 35), so they do not show up at all in degree resultatives. However, irriteren is used like ergeren 'annoy' in 36 by a growing group of speakers, although prescriptivists still frown upon this. For us, the interesting point is that those speakers who can substitute irriteert 'irritates' for ergeren in 36, can also do this in 37. In table 2, we present the four types of Dutch degree resultative constructions we have characterized above.

\begin{tabular}{|c|c|c|}
\hline Type & Structure & Example \\
\hline 1 & fake reflexive + predicate + verb & \begin{tabular}{|l|} 
zich slap lachen \\
'laugh oneself limpid'
\end{tabular} \\
\hline $2 \mathrm{a}$ & $\begin{array}{l}\text { (X's) body part } 1+\text { [uit/op X's body } \\
\text { part }_{2} \text { ] + verb }\end{array}$ & $\begin{array}{l}\text { de longen uit zijn lijf zingen } \\
\text { 'sing the lungs out of one's body' }\end{array}$ \\
\hline $2 b$ & $\begin{array}{l}\text { fake reflexive }+ \text { body } \text { part }_{1}+ \\
{[\text { uit/op] def. art. body part } 2]+\text { verb }}\end{array}$ & $\begin{array}{l}\text { zich de blaren op de tong praten } \\
\text { 'talk oneself the blisters on the } \\
\text { tongue' }\end{array}$ \\
\hline $2 \mathrm{c}$ & $\begin{array}{l}\mathrm{NP}+\text { def. art. body part } 1+[\text { uit/op } \\
\text { def. art. body part } 2]+ \text { verb }\end{array}$ & $\begin{array}{l}\text { iemand het hemd van het lijf } \\
\text { vragen 'ask someone the shirt off } \\
\text { the body' }\end{array}$ \\
\hline 3 & $\{$ fake reflexive $/ \mathrm{NP}\}+\mathrm{NP}+$ verb & $\begin{array}{l}\text { zich een bult lachen } \\
\text { 'laugh oneself a lump' } \\
\text { iemand een ongeluk slaan } \\
\text { 'hit somebody an accident' }\end{array}$ \\
\hline $4 a$ & $\mathrm{NP}+$ predicate + verb & $\begin{array}{l}\text { iemand verrot slaan } \\
\text { 'hit someone rotten' }\end{array}$ \\
\hline $4 b$ & $\begin{array}{l}\text { fake reflexive }+ \text { predicate }+[P+ \\
N P]+ \text { verb }\end{array}$ & $\begin{array}{l}\text { ergert zich groen en geel aan } \\
\text { iemand } \\
\text { 'be annoyed the hell out of by } \\
\text { someone' }\end{array}$ \\
\hline
\end{tabular}

Table 2. Four types of degree resultatives in Dutch.

In sum, Dutch presents four distinct constructions that degree resultative phrases occur in, where only one variant of one type (type 4a) does not contain a reflexive or body part/clothing bound by an argument of the verb. We consider this distribution in section 4.3 below. 


\subsection{Generalizations.}

Three generalizations emerge from the English and Dutch data with respect to transitivity, argument structure and grammatical functions, and body anchoring. Those generalizations lead us to a conclusion about the origin of the second-order resultative constructions.

To begin, we examine transitivity. All degree resultative phrases occur in a clause with a direct object, whether that direct object is genuine or fake. We attribute this requirement to the the first-order construction - the original literal resultative predicate. That is, nearly all sentences with secondary resultative predicates have a direct object. An exception is seen in $38 \mathrm{a}$, but it has a transitive counterpart, seen in $38 \mathrm{~b} .{ }^{13}$

(38) a. She wriggled free. / We squirmed loose.

b. She wriggled her way free. / We squirmed our way loose.

Other exceptions include verb + particle combinations such as $\{$ Piss/Fuck/Bugger off! $\}$, where an ordinarily telic interpretation can reasonably be called resultative (Cappelle 2007).

${ }^{13}$ Examples such as $38 \mathrm{~b}$ are never open to a degree interpretation, yet they have certain characteristics in common with degree resultatives. As Mondorf (2011) shows, the English way-construction (Jackendoff 1992, Marantz 1992, Israel 1996, Goldberg 1997) was in competition with a reflexive construction in early modern English, with both expressing result; next to a verb phrase such as force oneself into the house there is force one's way into the house. In the one instance, there is a reflexive bound by the subject (similar to English type 1 and Dutch types 1 and 3); in the other-a possessive, likewise bound by the subject (similar to English type 2 and Dutch type 2a). One striking difference between the English and Dutch way/weg constructions is that the latter requires a reflexive (Verhagen 2003) and does not allow a possessive: Zo blufte zij zich een weg uit Auschwitz 'Thus she bluffed her way out of Auschwitz' (lit. 'so bluffed she REFL a way out Auschwitz'). The relevant participant role, in other words, is most frequently expressed by a possessive in contemporary English and by a reflexive in Dutch. Early modern English was in this regard more like its continental West-Germanic sister languages (Mondorf 2011). The use of locally bound referents in resultative constructions, including the way-construction, is much more widespread in Dutch and German than it is in English. Our data show the same difference in frequency of locally bound referents between Dutch and English in degree resultatives. 
The next generalization concerns argument structure and grammatical functions. A particular interplay between argument structure and grammatical expression is a characteristic feature of degree resultatives. All degree resultatives have a direct object. However, in most types of degree resultative constructions the direct object is not licensed by the verb. Furthermore, if the object is licensed, it does not always satisfy the verb's selectional restrictions outside the resultative construction; the only exceptions are English type 5 and Dutch type 4a.

Further, some types of degree resultatives tend to involve only one argument of the verb, which appears as subject; the fake reflexive in English type 1 and Dutch types 1 and 3 is bound by that subject, as is the possessive within the body part NP in English type 2 (for those examples in which the possessive is bound) and Dutch type 2a. Note that the possessive in Dutch type 2a occurs with the object of a preposition, but due to the relationship of meronymy between the two terms referring to body parts, the possessive relation extends to the body part denoted by the direct object. Dutch Type $2 b$ has both a fake reflexive and a body part NP; the reflexive, which is bound by the subject, is interpreted as a possessive to the body part. Thus, the monovalent nature of these verbs shines through despite the presence of a direct object.

Additionally, sometimes arguments of the verb are linked to atypical grammatical functions. For example, in English types 3 and 6 the argument that is usually linked to direct object position appears, instead, in object of $\mathrm{P}$ position, while the NP that appears in direct object position is not an argument but rather an indicator of degree. Furthermore, in Dutch type 2c, a goal argument of a verb of communication that usually appears as the object of $\mathrm{P}$ appears in direct object position. Finally, in English types 2, 3, and 4, an oblique argument that is usually the object of $\mathrm{P}$ can appear as a possessive or as the object of a different P. In sum, degree resultatives in English and Dutch do not conform to ordinary patterns in linking arguments to grammatical functions. However, the relationship between argument structure and grammatical expression plays out differently in each language.

The final generalization concerns body anchoring. Degree resultatives are semantically "anchored" to the body of the affected argument. That argument may be repeated as a fake reflexive or it may be obligatorily coreferenced with a possessive (English types 1, 5; Dutch types 1, 2b, 3, 4b). Many degree resultatives explicitly mention body 
parts (English types 2, 5, and 6b). English type 6a treats clothing items as inalienable as body parts (Gordon 1986, Chappell \& McGregor 1996). ${ }^{14}$ The taboo terms found in English type 3 can be viewed as referring to internal, inalienable body parts (in that they will always belong to the affected argument, even if they are physically separated). This is clear for bodily effluents (kick the shit out of NP), but it is also true for the frequent expletive hell (knock the hell out of NP), where one still feels the historical effects of an exorcism (Hoeksema \& Napoli 2008). Likewise, in Dutch type 3, illnesses such as tuberculosis are internal to the body, and even fictional/imaginary/nonexistent conditions such as schompes and rambam are perceived as inalienable. The secondary predicates used as intensifiers in English types 1 and 4 tend to denote properties of the body (to pieces, stiff, sick) or of the mind (silly, numb). Silly, for example, in a sentence like I'll slap you silly, conveys senselessness, a state of being unable to think. However, these predicates never denote more controllable or behavioral properties (such as rich, good, sweet, polygamous). The same wholeness is observed in Dutch type 3, where the second NP of the ditransitive is all-encompassing: an accident, typhus, a stroke-never something incidental such as a hangnail or a stubbed toe. Diseases seem like very different entities from body parts. However, some recent discussions of inalienable possession have stressed that this category extends beyond body parts, to properties of mind and body, such as happiness and health (see, among others, Rooryck 2017).

Based on these generalizations, we offer an account for the emergence of second-order readings of literal resultatives. When a result is extreme in that it hits an absolute endpoint plus it has a holistic effect on the entity it is predicated of, a degree interpretation becomes available simply by virtue of that literal meaning. That is, since the literal meaning is extreme in appropriate contexts, it can be used as a hyperbole in other contexts that are close to appropriate, and, eventually, it can be used entirely metaphorically in any context. Body anchoring is the key here: It assures such a holistic effect and thus predisposes the construction toward allowing a degree reading to emerge.

${ }^{14}$ Of course, the body part metaphor can become tenuous at times, as when the LA Times writes about taxing "the socks off big trucks" (August 20, 1983). 
Further, the play between argument structure and grammatical functions typical of these constructions also contributes to the likelihood of a second-order reading. Here the literal reading can range from odd to truly bizarre to impossible. How does one annoy pants, for example, or charm socks or sing lungs? Thus, when faced with annoying pants off a person, one scrambles to see the pants as a relevant extension of the person and, thus, seeks a reading in which, say, the person is so very annoyed, she starts shedding clothing (perhaps because she is shaking so hard?). The metaphorical reading itself predisposes one toward a degree interpretation. One can certainly find resultatives under a literal interpretation with objects that are fake, as in 39a, and even with objects that are fake reflexives, as in $39 \mathrm{~b}$.

(39) a. She ran the jogger off the road (by swerving her car).

b. She drove herself to distraction.

However, the very creativity of using fake objects and fake reflexives pulls one to the margins of what the grammar will allow, forcing speakers to interpret language creatively. This is now the realm of the nonliteral, and that gives one license to associate other readings with a given construction.

\section{Historical Developments.}

We conducted a diachronic study of resultatives used for intensification - that is, degree resultatives - in English and Dutch based on the data from over the past 200 years. For English, we used the Corpus of Historical American English (COHA, Davies 2012). ${ }^{15}$ For Dutch, we used Delpher. Both online corpora allow one to search by decade. For COHA, the decades run from 1810 to 2010; for Delpher, we restricted ourselves to the period 1810-1995 (Delpher includes materials only up until 1995, so for the last decade, the 1990s, our data represent only a half-decade). The COHA data are roughly the same in size for all decades (on average 20 million words per decade) with the exception of the first two decades, the $1810 \mathrm{~s}$ and $1820 \mathrm{~s}$, which are 1.2 million and 6.9

\footnotetext{
${ }^{15}$ Our figures 1-3 and tables 3-9 below are based on data from only these two sources. Unless otherwise indicated, the examples in the text of the paper are also from COHA and Delpher.
} 
million, respectively. The Delpher data are more lopsided, with significantly less data from the decades between 1810 and 1890 compared to the decades after 1890, and a steep decline in the 1940s and 1950s. However, our claims in this paper concern very robust trends that are affected only marginally by the varying amount of data from decade to decade. For example, the 1930s material consists of 3,151 tokens, whereas the 1940s material of only 1,509 tokens (the drop is due to paper shortages during the war and in the postwar period). Yet the number of predicate types is 45 in each decade.

We did a systematic search for all secondary predicates that we either knew or hypothesized to be involved in degree resultatives (such as to death, limp, and so on). In COHA, we searched for all verbs that combine with the predicate in question (using lemma-search). In Delpher, unfortunately, no such option was available. Instead, we had to do the search for verbs by hand. ${ }^{16}$ Delpher is considerably larger than COHA. This is reflected in the fact that we found 4,962 instances (tokens) of degree resultatives in COHA and 28,359 in Delpher. Nonetheless, we found somewhat more variety in predicate types in the English data.

We searched for occurrences of each predicate since 1810, isolated the ones that were resultative predicates, and then made judgments as to whether the constructions each predicate occurred in were open to a degree resultative interpretation. Not all combinations of a resultative predicate and a verb necessarily have a degree reading even when they fit one of the construction types outlined in section 4. For example, while dood 'dead' is a common predicate in Dutch degree resultatives today and historically, there are many combinations that we view as regular (literal) resultatives, including doodschieten 'shoot dead', doodhongeren 'hunger/starve to death', doodvriezen 'freeze to death'. In contrast, for zich doodlachen 'laugh oneself to death', intensification is the most likely reading.

In some cases, it is not easy to tell hyperbole apart from literal interpretation without help from the context. For instance, zich kromwerken 'work oneself bent' will most likely be a hyperbole when said of a young man who is working hard at his job in advertising; it will be literal when said of an old farm hand who has done hard physical

\footnotetext{
${ }^{16}$ Now there is a more advanced online historical corpus of Dutch, nederlab.nl, but at the time of writing this resource was still being developed.
} 
labor most of his life. An expression such as zich ongans eten 'eat oneself nauseous' might be used to describe a situation in which so much food was eaten that the eater vomited, but it can also be used to indicate simply that a lot was eaten. In some instances, there was not enough information to tell us whether we had a literal or degree reading. In such instances, the primary criterion we used for interpreting a construction as a degree resultative was the presence of an implication of extreme intensity or amount. Anyone approaching this kind of issue will have to make similar judgment calls.

We divided the two centuries into 4 periods of 50 years for comparison. We see considerable growth in the number of predicate types, less so in the number of tokens per million words. In COHA, the latter show fairly random swings in the 19th century, ranging from to 9.2 tokens per million words in the $1810 \mathrm{~s}$ to 3 tokens per million words in the $1840 \mathrm{~s}$. On average, we found 7 tokens per million words in the 19th century data, after which that number slowly crept up to 17 per million in the 1990s.

Strikingly, the diachronic corpora show that new, emerging predicates do not replace old ones, but supplement them. Basically, the later the period, the more predicates one finds. Further, once a predicate appeared, it kept reappearing. Thus, we witness (near) monotonic growth in the number of predicates that occur in degree resultatives. This is true for both English and Dutch.

For example, the English resultative construction laugh oneself sick was first attested in 1773 (according to the Oxford English Dictionary). Since that time, it had to compete with many newer idioms (laugh one's head off, laugh oneself limp, laugh oneself into a tizzy, laugh one's socks off, laugh one's booty off, and so on), and yet there are no signs of it becoming obsolete. Only a few expressions have disappeared and those were rare to start with; we cite worry pallid, in 40.

(40) Because she is worrying herself pallid about you.

(Wodehouse, Laughing Gas, p. 29)

Other expressions persisted or evolved into a slight variant, as with beat \{hell/tarnation\} out of $X$, which is currently adorned with a definite article: beat the \{hell/tarnation out of $X$ (Hoeksema \& Napoli 2008).

With respect to Dutch, degree resultatives are first attested around 1600, that is, a few decades before they are attested in English (as far as 
we have been able to establish). Presumably, they are somewhat older than the first printed attestations, but it is difficult to say how much older. Similar to our findings for English, we found few cases that became defunct, as in 41, which is from the 1920s.

(41) Daarover prakkezeeren ze zich half mal.

Thereabout ponder they REFL half mad

'They are thinking hard about that.'

(De Gooi- en Eemlander, March 26, 1927:7)

Note that the use of half mal in 41 confirms our earlier claim that what is important in degree resultatives is the availability of a scale, not the endpoint (or a sense of maximality) itself (see discussion in section 3).

In listing the secondary resultative predicates in the figures below, we include the predicate itself along with any material in the degree resultative that is not the verb, a fake reflexive, or an argument of the verb. In other words, for examples with laugh X's head off and laugh oneself silly, we list head off and silly as secondary predicates. Thus, we do not count head(s) off in her head off, his head off, and our heads off as three different secondary predicates; instead, we only count lexically distinct predicates. In figure 1 below, we chart the number of secondary predicates appearing in degree resultatives in English and Dutch for each 50-year period.

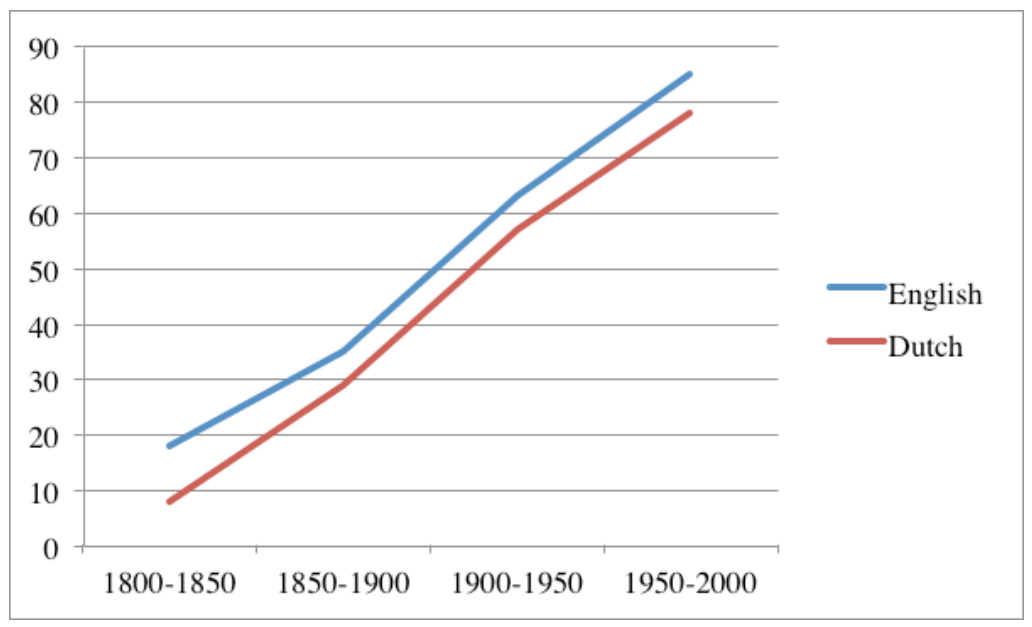

Figure 1. Number of lexically distinct secondary predicates in English and Dutch degree resultatives. 
In part, the consistent increase in the number of lexical items that serve as secondary predicates in degree resultatives is due to the continuous rise of expletive constructions - both in English and in Dutch - over the time span in figure 1 (Hoeksema \& Napoli 2008). For example, shitless is a relatively recent addition (1950's), probably based on earlier, nontaboo, witless, in combinations such as The attack scared us shitless. As time passed, the number of new nontaboo secondary predicates in degree resultatives, such as out of his/her skull, also continuously rose. The oldest attestation of a degree resultative with this secondary predicate was found in a movie script from 1968 (although more literal examples are attested earlier).

(42) Woman (laughing):

Look at that!

Another woman (laughing): Makes himself right at home!

Man (laughing):

Soused out of his skull.

(Perry, The Swimmer)

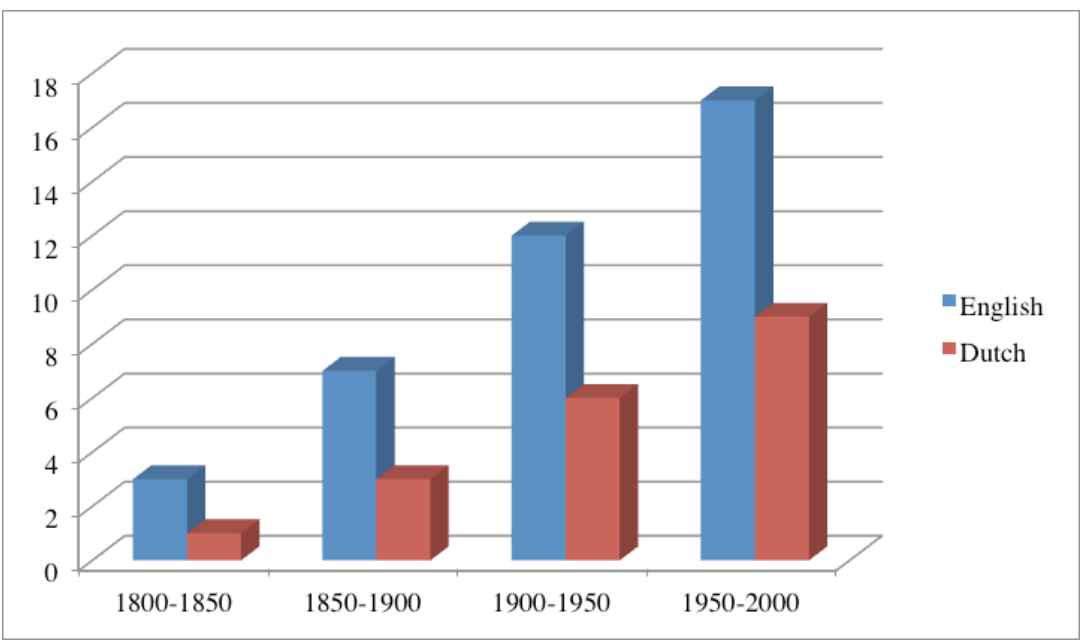

Figure 2. Number of different types of intensifier constructions in English and Dutch that express body part removal.

Many other body-part idioms are also fairly new. The English bodypart/clothing off construction (Cappelle 2014, see also section 6.4 below) grows from 0 in the first half of the 19th century to 3 in the second half 
of that century to 7 in the first half of the 20th century and to 12 in the second half of that century. If we include in our count variations due to extra adjectives, that number would be even higher (for example, worry one's pretty little head off, work one's damn ass off). In figure 2, we show the increasing number of idioms that express body part removal in intensifying constructions in the two languages.

However, not all types of degree resultatives increase in token frequency throughout the two centuries we are considering. One of the more prominent constructions is type 1 in English and type 4 in Dutch: the predicates to death/dood, which peak around 1900 in English (a little later in Dutch) and then decline a bit (presumably as a result of new competitors stepping in, as suggested in Gyselinck \& Colleman 2016b). In figure 3 , we show the number of new combinations verb + to death/dood per half century.

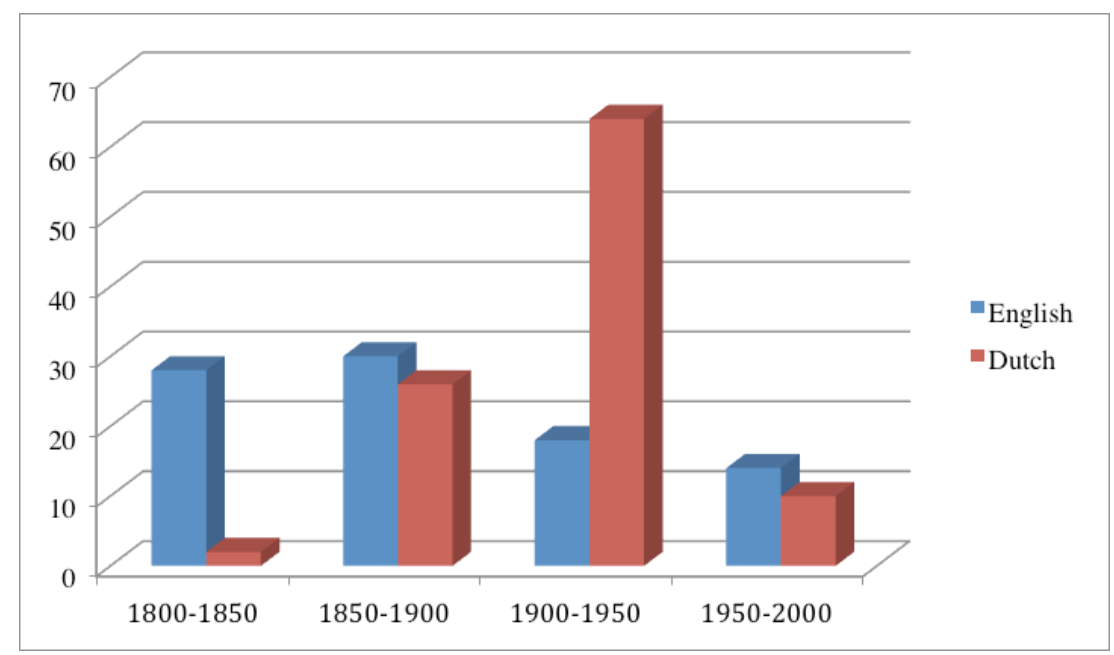

Figure 3. New combinations verb + intensifier to death/dood per half century.

Dutch appears to follow English at a distance. In the first half of the 19th century, we found no clear cases of intensifier uses of dood in our Dutch material. However, the large scientific dictionary of Dutch, Woordenboek der Nederlandsche Taal (WNT; entry "dood"), mentions four degree resultatives attested from the 17th century onward, for 
example, zich doodschamen lit. 'to shame oneself dead', that is, to be ashamed to death'. Dutch resultatives with dood peak about 1930, and then slowly decline. Hoeksema (2012) notes a similar decline for dood as a modifier in Dutch elative compounds (doodeenvoudig 'dead simple', doodeng 'dead scary') in the second half of the 20th century. Gysselinck \& Colleman (2016b), likewise, found a decline in productivity of Dutch dood-resultatives, using different measures (such as the number of unique verb + intensifier combinations divided by number of tokens). ${ }^{17}$ This decline seems to be in lockstep with the developments in English and may well represent a much wider trend among intensifier constructions in the (western) European Sprachbund (see Haspelmath 2001, Heine \& Kuteva 2006); we leave that larger issue to subsequent research. Below we note further similarities between English and Dutch, pointing toward English influence on Dutch.

One area where English and Dutch degree resultatives differ considerably is the use of reflexives. Fake reflexives occur in both languages, but Dutch uses them to a much greater extent than English. Our English data have between 8\% (1980s) and 18\% (1880s) cases with fake reflexives. In Dutch, their number varies from 52\% (1880s) and $80 \%$ (1940s). The preponderance of fake reflexives in Dutch may be related to the fact that Dutch has many inherently reflexive verbs, that is, verbs whose reflexive object is not an argument (for example, zich schamen 'be ashamed', zich generen 'be embarrassed', zich ergeren 'be annoyed', zich vervelen 'be bored'), in contrast to English, which has relatively few inherently reflexive verbs, such as perjure oneself and pride oneself, but very little else. Thus, when Dutch employs fake reflexives in degree resultatives, it is availing itself of the already muchused option of having nonargument reflexive objects. Moreover, we should point out that the inherently reflexive Dutch verbs listed above are among the most common verbs to be found with degree resultatives.

\section{Verb + Secondary Predicate Collocations in Degree Resultatives.}

The variety of combinations of verbs and secondary predicates in degree resultatives has been increasing slowly but steadily over the past four hundred years in both English and Dutch. This growth can be viewed as evidence of the productivity of the various constructions that degree

${ }^{17}$ For a list of verbs involved, see Gysselinck \& Colleman 2016b. 
resultative predicates can occur in (Cappelle 2014, Perek 2016). Certain verbs or semantically-based groups of verbs occur with an ever-growing assortment of secondary predicates, and certain secondary predicates occur with an ever-growing assortment of verbs. A closer look reveals that verbs that welcome degree resultatives fall into semantic groups; an examination of frequently occurring verb groups and secondary predicates offers a greater understanding of why degree resultatives are best viewed as second-order constructions.

For example, Margerie (2011), in a discussion of the very common secondary predicate to death, notes that it originated in a literal resultative (as in starve the peasants to death); but, quite early on, in the 17 th century, a degree resultative usage emerged, and even what Margerie calls a degree modifier usage (as in her modern example I am sick to death of Star Wars quotes). Middle-period degree resultative usage of this predicate involves frequent combinations with negative psychological verbs, including bore, frighten, scare, annoy, and hate. Combinations with positive verbs - as in love somebody to death, nowadays fairly common - are not attested in our corpora before 1950 . Thus, one can see a development over time of the secondary predicate to death from a strictly literal reading (with verbs such as starve) to a degree reading based on a metaphor (with main predicates such as sick in the sense of "annoyed") to a reading that is (nearly) exclusively degree (with verbs such as love). This progression shows that by 1950, the degree interpretation of resultatives becomes so firmly established that it casts aside literalness and no longer even relies on metaphor; the secondorder reading is solid. Below we present details on three of the most frequently used verb groups and the secondary predicates they collocate with, and on two of the most frequently used secondary predicates and the verbs they collocate with.

\subsection{Work-Related Verbs.}

There are many work-related verbs, and there are several secondary predicates that appear with them in degree resultatives. Consider first occurrences of work itself, as in work one's fingers to the bone or work one's tail off. While both mean working hard, the former mainly concerns labor involving the hands, such as cleaning, scrubbing, typing, knitting, sewing. A quarterback training hard may be said to be working his tail off, but not to be working his fingers to the bone. This 
observation is reflected in the set of verbs associated with one's fingers to the bone and one's tail off (we restrict ourselves to clear degree resultatives, and ignore ones that might be more (nearly) literal in drastic situations, such as I'll cut your tail off if I ever see you near my daughter again). Note that for both these secondary predicates, work is the most frequent verb on the list of collocates given in table 3. In fact, the two sets are very similar, with one exception: freeze is also relatively common with one's tail off, but not with one's fingers to the bone. We come back to the verb freeze in the next subsection.

The resultative play $\{$ his/her\} fingers to the bone can describe playing guitar or some other instrument in which the fingers are the only crucial articulator (for example, guitar or piano rather than bassoon or trumpet) but not, for example, team sports, as in \#The Sixers played their fingers to the bone, or frolicking children, as in \#We let the kids at our daycare play their fingers to the bone. That is, while a degree resultative using one's fingers to the bone clearly relies on metaphor, the literal meaning of the secondary predicate still lingers.

Note that the senses of play that do not combine with one's fingers to the bone are perfectly acceptable with other types of resultative predicates, as in The Sixers were playing their tails off or The kids at the daycare were playing their hearts out. These data show that degree resultatives are sensitive to polysemy. Still other uses of play are illustrated in 43.

(43) a. Laurence Fishburne played the hell out of the deranged, crazy and talented Ike Turner in "What's Love Got To Do With It".

b. We played the hell out of that video game.

Dutch has an idiom involving fingers, zijn vingers blauw 'one's fingers blue', which may be used for intensifying purposes. Like its English counterpart, it is used with verbs involving hand actions, albeit a different set of verbs. In particular, verbs of writing and counting (typically counting money, involving manipulation of coins or bills) are involved (we leave out a lot of verbs that appear less frequently with vingers blauw). The examples with werken 'work' are less common, and they sound less idiomatic to our ears. All but one of the 10 examples are from serialized novels or news articles translated from English. We 
suspect that the originals had the idiom fingers to the bone, for which vingers blauw is the best Dutch approximation. In table 3 and the following tables, \# indicates number of instances found in the data.

\begin{tabular}{|l|c|c|c|}
\hline $\begin{array}{l}\text { Verb } \downarrow \\
\text { Intensifier } \rightarrow\end{array}$ & \#tail(s) off & \#fingers to the bone & \#vingers blauw \\
\hline dance & 1 & - & - \\
\hline drill & 1 & - & - \\
\hline run & 1 & - & - \\
\hline work/werken & 21 & 48 & 10 \\
\hline grind & - & 1 & - \\
\hline sew / naaien & - & 1 & 1 \\
\hline slave & - & 1 & - \\
\hline write/schrijven & - & - & 233 \\
\hline pen/pennen & - & - & 18 \\
\hline type/typen, tikken & - & - & 25 \\
\hline count & - & - & 76 \\
\hline
\end{tabular}

Table 3. Verbs collocating with tail off, fingers to the bone, and vingers blauw.

In general, work frequently shows up in degree resultatives, and not just with the two English secondary predicates examined in table 3. In our English corpora, it ranks as the third most frequent verb, behind beat and scare. In our Dutch corpora, werken 'work' comes fifth.

What is striking about the two English secondary predicates in table 3 is their strong connection to the most basic sense of work ('expend effort'). Other secondary predicates exhibit a weaker connection to that basic sense. Consider, for example, our data for one's ass off. Table 4 shows that not only are there more verbs that collocate with this secondary predicate, but the semantic range of those verbs is greater as well, including laugh and related verbs, such as smile and grin; verbs such as lie and perjure, and a few verbs that typically take an object, such as bore or sue. The more taboo secondary predicate (with ass) is more productive than the less

${ }^{18}$ Slave as a verb always requires a complement, though that complement is not an NP except in degree resultatives. Compare slave (*my day) away at something to slave my fingers to the bone. 
taboo one (with tail) in degree resultatives, which is expected given the prevalence of taboo terms in degree resultatives in general. In a few cases, the verb is transitive and the possessive pronoun is not coreferential with the subject (as in He will sue your ass off).

\begin{tabular}{|l|c|l|c|l|c|}
\hline Verb & $\#$ & Verb & $\#$ & Verb & $\#$ \\
\hline analyze & 1 & giggle & 1 & study & 1 \\
\hline bawl & 1 & grin & 1 & sue & 3 \\
\hline bore & 1 & laugh & 9 & sweat & 1 \\
\hline calculate & 1 & lie & 1 & train & 1 \\
\hline cheer & 1 & negotiate & 1 & tromp & 1 \\
\hline chew & 1 & perjure & 1 & wear & 2 \\
\hline drill & 1 & play & 1 & whip & 1 \\
\hline fight & 1 & run & 2 & work & 36 \\
\hline flatter & 1 & sing & 1 & write & 1 \\
\hline freeze & 17 & sprint & 1 & & 93 \\
\hline Total
\end{tabular}

Table 4. English verbs collocating with one's ass off.

In Dutch, the predicates that most often collocate with werken 'work' are uit de naad 'out of the stitch' and het schompes (see our comments below 31 regarding this item, which has no apparent independent meaning), as shown in table 5 . Other verbs typically denote work-related activities (or sports, which may be either a hobby or a job).

\begin{tabular}{|l|c|c|}
\hline Verb & \#(zich) uit de naad & \#(zich) het schompes \\
\hline werken 'work' & 252 & 4 \\
\hline lopen 'walk, run' & 38 & 2 \\
\hline rennen 'run' & 10 & - \\
\hline other 32 verbs (total) & 69 & - \\
\hline other 5 verbs (total) & - & 7 \\
\hline Total & 369 & 13 \\
\hline
\end{tabular}

Table 5. Dutch verbs collocating with uit de naad and zich het schompes. 
Perhaps the prominence of lopen 'walk' and rennen 'run' on this list might seem odd, but only until one examines the context. A typical example is given in 44 .

(44) Je loopt je uit de naad voor deze provincie en dan you walk REFL out the stitch for this province and then proberen ze je af te schilderen als een ratelslang. try they you PRT to paint as a rattlesnake

'You run your ass off for this province and then they try to paint you as a rattlesnake.'

It turns out that the verbs lopen 'walk' and rennen 'run' in such examples either denote sport-related running or are used in the sense of work, not locomotion.

\subsection{Freeze One's Extremities Off.}

A statement such as $I$ am freezing is ambiguous between a reading where a person is in the process of turning into ice and a more common reading where the person feels exceedingly cold. The latter reading presumably originally derived from the former as a hyperbole. Nowadays, it is no longer felt to be a hyperbole, hence the need to reinforce it with a degree resultative construction, usually involving body extremities, as shown in table 6 below. This need for an added degree resultative construction may be strengthened somewhat by the fact that ordinary boosters for freeze seem to be in use only for the literal 'turning into ice' reading of the verb. Consider the examples in 45 .

(45) a. It is freezing hard as rock.

b. \#Mary is freezing hard as rock. (compare with Mary is freezing to death.)

In table 6, we list the nouns in our corpora that fill the $\mathrm{X}$ position in freeze one's $X$ off in degree resultatives only. The nouns listed were found in $\mathrm{COHA}$, but the Internet is replete with examples that involve references to just about any bodily extremity in combination with to freeze off. 


\begin{tabular}{|l|c|}
\hline Body part & $\#$ \\
\hline arse & 2 \\
\hline ass & 17 \\
\hline balls & 8 \\
\hline buns & 4 \\
\hline buts & 4 \\
\hline extremities & 1 \\
\hline nuts & 4 \\
\hline tits & 2 \\
\hline Total & $\mathbf{4 2}$ \\
\hline
\end{tabular}

Table 6. Nouns that fill the $X$ position in freeze one's $X$ off.

The fact that degree resultatives with freeze involve extremities follows from the fact that these may, in fact, literally freeze off occasionally (from frostbite). However, the body parts that most easily freeze, such as ears, toes, or corneas, are not the most popular in the hyperbolic use. Rather, there is a clear preference for taboo terms and mock taboo terms (euphemisms) for more polite conversation (assets, extremities), which are more generally used for intensification (see Napoli $\&$ Hoeksema 2009), and hence less likely to be misunderstood in the more literal sense of limbs freezing off. Indeed, the body parts extend to cases where actual freezing off is less likely, such as freezing one's ass off.

The Dutch cognate of English freeze is vriezen. The literal 'turn into ice' interpretation may be intensified by a resultative CP; thus, it is not among the types found in table 2 (which are limited to secondary predicates).

(46) Het vriest dat het kraakt.

it freezes that it cracks/squeaks

'It is freezing cold.'

In other words, 'it freezes so hard that it produces cracks' (or creaky noises). Unlike English freeze, vriezen cannot be used to describe animate beings that are extremely cold, which may well be why the 
Dutch verb does not occur in degree resultatives. ${ }^{19}$ In contrast, the cognate verb frieren in German is much more like English freeze; it can be used with animate subjects to indicate extreme cold, and, accordingly, degree resultatives occur commonly with this verb, particularly taboorelated ones, as shown in $47 .^{20}$

(47) a. Die Freunde frieren sich die Eier ab. the friends freeze REFL the eggs off 'The friends are freezing their nuts off.'

b. In Canada friert man sich den Hintern ab in Canada freezes one REFL the posteriors off 'In Canada you freeze your ass off.'

With regard to English, then, we note that just as in the case of fingers to the bone combined with work-related and other verbs (see subsection 6.1), the choice of secondary predicates occurring with freeze

${ }^{19}$ In Dutch, the standard way of saying that one is cold is NP het koud hebben 'NP is cold' lit. 'NP it cold have'. The semantically important predicate in this construction is syntactically secondary: The main verb hebben is a dummy and the AP koud denotes the property predicated of the subject. Other constructions with hebben and various other APs include het druk hebben 'be busy' lit. 'it busy have', het moeilijk hebben 'have a hard time' lit. 'it tough have'. Just as in English, the presence of the syntactic secondary predicate precludes the addition of a resultative secondary predicate (literal or degree). Instead, intensification is expressed by ordinary adverbs, as in het erg koud hebben 'be very cold' lit. 'it very cold have'.

${ }^{20}$ The verb bevriezen (consisting of the same root plus the prefix be-) can take an animate subject and can be used in hyperbole: Ik bevries zowat 'I am almost turning into ice'. One might therefore expect it to allow degree resultatives. In fact, however, be-verbs resist co-occurrence with resultatives (Hoekstra et al. 1987), and we have found no examples with bevriezen. Note, however, that we have found a few examples of other $b e$-verbs with resultatives, including degree resultatives: De man is helemaal te pletter bestraald 'The man was radiated to bits' lit. 'the man is completely to pieces radiated' (Libelle, February 12, 2016:50). These rare examples are also problematic for the claim by Kratzer (2005) that only intransitive verbs may combine with resultatives, since they are strictly transitive. 
in degree resultatives is neither completely arbitrary (otherwise one might also expect \#I am freezing my heart out or \#I am freezing my lips $o f f)$, nor is it completely motivated by probability in real life.

\subsection{Head-Related Activities.}

A common predicate in degree resultatives is one's head off, which occurs with a range of verbs (though not freeze), as seen in table 7. Again, we focus on degree readings only, so the many cases of chopping, tearing, blowing, cutting, lopping, knocking, or ripping someone's head off in our corpora are not included. ${ }^{21}$

\begin{tabular}{|l|c|l|c|l|c|}
\hline Verb & $\#$ & Verb & $\#$ & Verb & $\#$ \\
\hline bark & 7 & listen & 1 & shout & 4 \\
\hline bawl & 11 & neck & 1 & shriek & 2 \\
\hline bitch & 1 & paint & 1 & sing & 4 \\
\hline cry & 2 & play & 2 & smoke & 1 \\
\hline dance & 2 & publicize & 1 & sneeze & 5 \\
\hline drink & 4 & ring & 3 & talk & 26 \\
\hline eat & 16 & roar & 1 & work & 14 \\
\hline giggle & 3 & run & 1 & worry & 4 \\
\hline holler & 8 & scowl & 1 & yap & 2 \\
\hline hustle & 1 & scream & 30 & yawn & 2 \\
\hline laugh & 36 & screech & 1 & yell & 23 \\
\hline lie & 10 & & & & 231 \\
\hline Total & &
\end{tabular}

Table 7. Verbs collocating with one's head off.

${ }^{21}$ Some of these excluded instances have a strongly hyperbolic flavor, for example, when someone threatens to bite another's head off. Yet this does not, in our opinion, constitute an intensification of the verb bite. To see the distinction we are making, contrast that situation to the case of biting one's own head off, rather than another's, the former of which might be used with a degree reading. For example, when a dog gets a bone to gnaw on, one might say Fido can bite his head off now. The degree reading emerges here: Fido can bite to his heart's content. 
The verbs in table 7 , diverse though they are, mostly represent actions that involve the use of one's head, such as yelling, talking, crying, singing, and smoking. Only a few do not fit this pattern, such as work and paint. It is possible that for some speakers, working one's head off is a more socially acceptable alternative to the more common working one's ass off. This is certainly what the following exchange from the online Corpus of American Soap Operas dialogues suggests: ${ }^{22}$

(48) Will: Wow, um... I mean, thank you. This is incredible. I'll do your company proud, Mr. DiMera. I'll work my ass-I'll work my head off.

Stefano: Or both.

There are also a few cases of psych verbs in table 7: puzzle, worry, wonder. These are atypical-occurring only once each. Thus, although they denote a mental activity, and could hence be seen as an activity that involves the use of one's head, they take a backseat to activities that can be detected from the outside, such as laughing, screaming or talking.

It is not common in linguistics to assign verbs that denote headrelated activities to a separate category, like psych verbs or verbs of motion. Yet we are not surprised to find it helpful in circumscribing the set in table 7 rather well. As we noted in the case of fingers to the bone and freeze one's extremities off, the literal sense of verbs and the literal sense of the predicates they collocate with can affect the appropriateness of the collocation in idiomatic degree resultatives. Indeed, sometimes, the fact that degree resultatives are related to ordinary (literal) resultatives may lead to puns, such as the following, where they refers to the Islamic State.

(49) I'm sure they will love you too - they will probably love your head off!

(Michael Smith News, February 23, 2015)

Dutch does not have degree resultative idioms comparable to one's head off. In general, talking about severed heads is less common in the Dutch corpora, including the more literal cases comparable to English

${ }^{22}$ This example is from the episode of Days of Our Lives aired July 26, 2010. 
I'm gonna blow your head off, although these are grammatical when actual decapitation is described. Consider the examples in 50 (and compare them to example 51 in the next section).

(50) a. *De baby schreeuwt zijn hoofd eraf. the baby screams his head off 'The baby is screaming his head off.'

b. De beul hakt zijn hoofd eraf. the executioner hacks his head off 'The executioner is chopping off his head.'

The examination of degree resultatives, then, makes one note a class of verbs that otherwise might have never been referred to in describing the syntax of English.

\subsection{The $\{$ Clothing/Body Part $\}$ Off NP.}

In table 1, we distinguished English type 6a from English type 6b. The former involves clothing (the socks off NP); the latter, body parts (the ears off NP). There is a marked difference between the verbs that appear in these two subtypes. In our corpora, psych verbs that typically place their experiencer argument in direct object position (annoy, bore, charm, frighten, scare, shock, terrify, wow, the group referred to as "amuse" verbs in Levin 1993) are common in degree resultatives only with the clothing expressions, as in $51(=21){ }^{23}$

(51) I think we could bore the pants off the viewers if we did something of that kind.

${ }^{23}$ Levin (1993:191) lists another class as "admire" verbs, which have experiencer subjects. Levin does not list resultatives as an option for these verbs, but some of them appear in resultative constructions other than those in English type 6 , as in love somebody to death, respect the hell out of someone. It should be noted that the class of resultatives we consider here is larger than the one considered by Levin. However, our findings support Levin's claim that resultatives are sensitive to the two subclasses of experiencer verbs discussed here. There is also a third group, with PP complements, which we have nothing to say about here. 
That is, this type of psych verb was most common in English type 6a constructions, as seen in table 8 .

\begin{tabular}{|l|c|c|}
\hline \multicolumn{1}{|c|}{ BODY PART } & $\#$ & $\begin{array}{c}\text { \% psych verbs } \\
\text { with experiencer typically as DO }\end{array}$ \\
\hline arse/ ass off & 97 & $1 \%$ \\
\hline butt off & 23 & - \\
\hline ears off & 12 & - \\
\hline head off & 248 & $2 \%^{24}$ \\
\hline tail off & 24 & - \\
\hline \multicolumn{1}{|c|}{ CLOTHING } & & $35 \%$ \\
\hline pants off & 65 & $56 \%$ \\
\hline socks off & 9 & -25 \\
\hline shirt off someone's back & 24 & \\
\hline
\end{tabular}

Table 8. NPs denoting body parts and clothing in English type 6; psych verbs versus all others.

Why can we bore, shock or charm the pants or socks off people but not the ears or head off them? Certainly, there are multiple other ways to intensify such verbs: annoy the hell out of someone, annoy someone to death. We do not know why subtype 6a is so rare with psych verbs. What we do find interesting - and worth noting - is that the group of psych verbs with experiencer objects acts as a unified group in preferring subtype $6 \mathrm{~b}$ over $6 \mathrm{a}$, to the extent that they appear at all in one of the type 6 constructions.

${ }^{24}$ There were 5 cases of worry with one's head off in COHA. They all involve intransitive worry, as in ia; what seems to be ruled out are transitive cases with intensifier predicates, as in ib.

(i) a. Now don't worry your head off any more about mortgages and loans, Emily.

b. That worries me. *In fact, it worries my head off.

${ }^{25}$ While we have no examples of psych verbs from COHA for this particular expression, they are easy to google:

(i) Getting a person to remove their footwear on a hot, damp day is no small achievement, but Jeff Goldblum could charm the shirt off your back (give him 15 minutes longer).

(The Independent, July 21, 1993) 


\subsection{Thinking Long and Hard.}

By and large, the set of verbs involved in Dutch degree resultatives is similar to the set employed in English. However, verbs of thinking represent a major difference between the two languages. While these verbs occur in degree resultatives only rarely in our English corpora, they are robustly attested in Dutch degree resultatives of type 1, mostly with the secondary predicate suf 'drowsy, stupid'. Examples are given in 52.

(52) a. Ik heb mij suf gedacht en kan geen uitweg vinden. I have REFL stupid thought and can no way out find 'I have been racking my brain and can find no way out.'

b. Ze piekerden zich suf. they pondered REFL stupid 'They pondered long and hard.'

c. Hij prakkizeerde zich suf, he deliberated REFL stupid zonder een antwoord te vinden. without an answer to find 'He deliberated hard, without finding an answer.'

The Dutch predicate suf is sufficiently frequent in our material to lend itself to a diachronic study. While the earliest occurrences are all collocated with verbs of thinking - which makes sense, given its meaning 'drowsy' - we have observed a gradual extension of this secondary predicate to other categories of verbs. First, suf is found with verbs such as zoeken 'seek' or studeren 'study', which likewise are associated with mental activity. Then, in the course of the 20th century, it extended further to a wide range of other verbs such as werken 'work', kankeren 'complain' or lachen 'laugh'. Table 9 summarizes our corpus data for this predicate. 


\begin{tabular}{|c|c|c|}
\hline Period & \# (tokens) & \% verbs of thinking \\
\hline 1800 & 3 & $100 \%$ \\
\hline 1850 & 88 & $78 \%$ \\
\hline 1900 & 571 & $88 \%$ \\
\hline 1950 & 785 & $56 \%$ \\
\hline $2000^{26}$ & 76 & $13 \%$ \\
\hline
\end{tabular}

Table 9. Dutch type 1 degree resultatives with the secondary predicate suf.

The first occurrences of suf as a secondary predicate are ambiguous between a degree reading and a literal result reading, the two being hard to distinguish for verbs of thinking. Verbs of thinking form a "critical context" in the sense of Diewald (2002): a context compatible with a regular interpretation as well as a new grammaticalized interpretation. The increase in frequency in the second half of the 19th century suggests that the degree reading of suf takes hold in that period. Its eventual spread to other types of verbs (that do not denote mental activity) signals that the degree interpretation has become dominant, and that the original nonintensifier resultative meaning no longer prevents suf from combining with verbs not normally associated with drowsiness, such as laugh or complain.

The paucity of examples in English and Dutch of regular, nondegree resultatives with the verb think is probably a pragmatic matter, having to do with the fact that thinking about something does not usually affect the state that something is in. Still, a few such regular resultatives are attested. For instance, 53 is adapted from an internet posting.

(53) Ze denkt alles kapot.

she thinks all kaput

'She destroys everything by overthinking it.'

(Talentwerk, June 15, 2016)

Another example of a resultative with think is the title of the book by the Dutch comedian Toon Hermans, Ik denk me blij 'I think myself happy',

26 Our Delpher data do not include 21 st-century data, so we added 76 occurrences of zich suf from the newspaper database LexisNexis, period 2015October 27, 2017. 
with positive, uplifting poetry. In 54, we offer an example of our own, with a different verb of thinking, mijmeren 'muse, ponder'.

(54) Hij mijmerde zich in slaap.

he mused self in sleep

'He mused himself to sleep.'

In English, the use of resultatives with verbs of thinking is rare as well, but still possible, as shown in 55 .

(55) a. In one myth, Tepeu and Quetzalcoatl think everything into being.

(Gaia, September 19, 2017)

b. In order to increase the level of your happiness, you must learn the following techniques that will help you think yourself happy.

(Good Relaxation)

Thus, the use of degree resultatives with verbs of thinking is not entirely unexpected, in Dutch and in English. Degree resultatives with verbs of thinking in English are illustrated in 56 below (56a is from Corpus of American Soap Operas). ${ }^{27}$

(56) a. I don't want to think it to death.

b. Don't you think I've thought my bloody brains out over it?

c. [W] can think ourselves into a tizzy.

In conclusion, verbs of thinking can occur in resultatives. They are more common in degree resultatives than in regular resultatives, due to language-external reasons, in particular, the fact that thinking rarely causes a change of state in the object of the thought.

\section{Degree Resultatives and Other Evaluative Constructions.}

In many cases, degree resultatives are simply hyperbolically understood resultatives; they are metaphors that have become fixed expressions. The secondary predicates in these expressions may (but need not) be extended to other verbs where the original metaphor does not make as

${ }^{27}$ This is a line from the episode of All My Children aired March 7, 2011. 
much sense. For instance, Dutch zich te barsten eten 'eat (oneself) to (the point of) bursting' is a hyperbole, while the newer combination zich te barsten ergeren lit. 'annoy oneself to burst', or 'be annoyed to the point of bursting' makes less sense as a metaphor but is easily understood via analogy to the earlier cases with eten 'eat'.

Metaphor and analogy cannot account for all instances, though. We also found instances where the presence of a taboo expression or term of abuse seems sufficient to provide the kind of oomph needed for intensification (Napoli \& Hoeksema 2009). Consider one of the newest Dutch combinations: zich de takken ergeren 'be royally pissed off' lit. 'annoy oneself the branches/twigs'. To English ears (or Dutch ears 50 years ago), this combination does not make a lot of sense. However, the expression begins to make more sense when one considers the affixoid takke- 'twigs' meaning 'horrid, awful'. This use seems to come from takkewijf 'branches woman', presumably used originally to denote an old hag collecting firewood, which became a term of abuse for any woman (attested since 1984, according to van der Sijs 2001). ${ }^{28}$ Very quickly, the initial part takke- became a general pejorative affixoid, as in takkeherrie 'awful noise', takkeschool 'lousy school', takkebende 'fucking mess', etc. As is not uncommon for this kind of expressive item, it jumped easily to another construction (Napoli \& Hoeksema 2009 offer a variety of cases), and so around 2010 de takken 'the twigs, branches' shows up in degree expressions such as $57 .^{29}$

(57) Ik heb me jaren de takken geërgerd aan de manier I have me years the branches annoyed to the manner waarop de herdenking van D-Day [...] whereon the commemoration of D-Day

in beeld is gebracht. in view is brought

\footnotetext{
${ }^{28}$ Wijf is a derogatory term for women in present-day Dutch; similarly, Old English huswif 'housewife' became the derogatory hussy in English (Romaine 1999:94).

29 Book section, available at https://www.nrc.nl/nieuws/2012/09/07/900paginas-lang-gruwelen-1148109-a571032, accessed on January 31, 2019.
} 
'For years, I have been annoyed as hell about the manner in which the commemoration of D-day is depicted [on TV].'

(NRC Handelsblad, September 7, 2012:4)

Similar observations hold for the many terms for diseases found in Dutch. They were first used in maledictions (Krijg de tering, smiecht 'get tuberculosis, you jerk') and in pejorative compounds (teringherrie lit. 'tuberculosis' = 'damned noise'), and then were recruited by degree resultative constructions, as well as by negative polarity constructions (see Hoeksema 2001 for some discussion).

\section{Some Predictions of Our Account.}

We have treated degree resultatives as historically deriving from regular resultatives by semantic reanalysis. Unlike what is often suggested in the literature, degree resultatives are more than a mere bunch of idioms. They show productivity (as argued by Cappelle 2014) and form an increasingly important alternative to adverbs of degree. Nonetheless, they will never be able to completely replace adverbs of degree, due to their inherent structural limitations. The most important of these is a ban on particle verbs.

Both in English and Dutch, particle verbs do not take part in ordinary resultative constructions (Kayne 1985, Keyser \& Roeper 1992, Neeleman \& Weerman 1993). Particle verbs, if they are gradable, may be modified by adverbs of degree. Using the Lassy Groot corpus (which is much smaller than Delpher), via the interface PaQu (Odijk et al. 2017), we counted Dutch verbs most commonly modified by the degree modifiers zeer 'very', erg 'very', nogal 'rather', and flink 'strongly'. The top fifteen verbs were verschillen 'differ', lijken op 'look like', uiteenlopen 'differ', uitbreiden 'expand', waarderen 'value', lijden 'suffer', toenemen 'increase', afwijken 'deviate', houden van 'love, like', loven 'praise', veranderen 'change', bewonderen 'admire', opvallen 'strike, be noticeable', variëren 'vary', and tegenvallen 'disappoint'. Of these, 6-or $40 \%$ - are particle verbs. These 6 verbs occur 755 times with one of the aforementioned modifiers. In Delpher, we found only two examples of degree resultatives with particle verbs: ${ }^{30}$

${ }^{30}$ Example 58a is from Bataviaasch Nieuwsblad, March 13, 1909. Note that both optellen 'add' and aftrekken 'subtract' are particle verbs. Example 58b is from from NRC Handelsblad, February 15, 1982. 
(58) a. Niet lang had hij dat gewichtig ambt bekleed, not long had he that important position had

waarin hij zich suf kon optellen en aftrekken, wherein he self stupid could add and subtract,

toen de malaria hem te pakken kreeg.

when the malaria him to grab got

'Not long had he had that important position, in which he could add and subtract himself stupid, when malaria got hold of him.'

b. Deze leeft zich ongans uit in stofjes en staaltjes zonder this lives self sick out in materials and samples without zich om een inhoudelijke betekenis te bekommeren. self for a substantive content to concern

'This one knocks himself out in materials and samples without any concern for substantive content.'

Example 58b strikes us as especially bad, while $58 \mathrm{a}$ is somewhat better. The reason we find most compelling for this difference in acceptability was offered to us by an anonymous referee. The verbs of interest in 58a, optellen 'add' and aftrekken 'subtract', can appear easily with or without an object, so they can license the secondary predicate zich suf 'self stupid'. Other examples of verbs offered by the referee that can optionally, if marginally, take an object and license the secondary predicate zich AP include optreden 'perform on stage', afdingen 'talk down the price of something', afkijken 'cheat by spying during an exam', overgeven 'vomit', voorzingen/spelen 'demonstrate how something should be sung/played' (?dat hij zich suf optreedt/ afdingt/ afkijkt/ overgeeft/voorzingt that he is performing (etc.) himself silly'). In contrast, the verb of interest in 58b, uitleven 'to go wild, to knock oneself out' lit. 'live out' (seen in the discontinuous leeft plus uit) requires a fake object, being inherently reflexive. Under normal circumstances it is impossible for two co-occurring resultative secondary predicates to share the same (fake) object; hence $58 \mathrm{~b}$ is unexpected (and awkward).

Our overall main point here is that the number of particle verbs in our Dutch material is close to zero, whereas gradable particle verbs are actually very common. The situation in English is comparable. Gradable 
particle verbs abound, but not with degree resultatives. Our material does not contain any cases of degree resultatives with particle verbs.

Small differences between English and Dutch with respect to degree resultatives have to do with more basic lexical differences. The English verb love is found a fair number of times in degree resultatives (I love you to death/to pieces, they love the hell out of soccer), but its Dutch counterparts generally are not. The only Dutch counterpart to English love in degree resultatives that has come to our attention is the obsolete verb beminnen 'love', as in Hij bemint haar (helemaal) kapot 'he loves her (completely) broken'. ${ }^{31}$ This verb is straightforwardly transitive. In contrast, other Dutch counterparts to English love include houden van 'love, like', which takes a prepositional complement and as such cannot appear in degree resultatives, and liefhebben 'love' lit. 'sweet-have', which is a complex verb, similar to a particle verb. We have noted some cases of verbs with prepositional arguments partaking in degree resultatives (see section 4.1 above), such as talk something to death; these cases, however, involved verbs that may occasionally be used (with the same interpretation) as transitive verbs (let's talk syntax). In contrast, for Dutch houden van, there is no semantically related transitive use. The verb houden means 'hold, keep', and has no connection to the concept of loving or liking. Thus, we conclude that verbs with PP, rather than DP, objects, may occasionally take part in degree resultatives, provided that the relation between the verb and the PP object is semantically transparent.

\section{Conclusions.}

In this paper, we presented an overview and classification of resultative constructions in English and Dutch in which the resultative predicate has a primarily intensifying function. Our classification is based on the transitivity (or intransitivity) of the verbs involved, and the syntactic make-up of the resultative predicates. By bringing together a variety of constructions, we tried to show just how pervasive and varied the use of resultatives is in the expression of degree. In doing so, we set the stage for a diachronic study of the phenomenon. One of the main points of this

\footnotetext{
${ }^{31}$ The fact that beminnen can appear in a degree resultative is surprising in light of the fact that verbs with the be- prefix generally resist resultatives, as noted in note 20 .
} 
paper is that the degree readings have not always been around, but have developed in the course of the last several centuries.

The concept of second-order constructions provides an explanation for the connection between degree resultatives and ordinary resultatives. We proposed that some instances of first-order constructions - that is, ordinary resultatives - lose their literal meaning and become more flexible in their interpretation; the secondary predicate may now be interpreted figuratively, as a gradable property, which gives rise to a degree reading. Thus, degree resultatives are second-order constructions in the sense that they are derived from ordinary resultatives. Subsequently, the second-order construction may begin to allow novel combinations (for example, from scare somebody to death to love somebody to death). Such developments may not be that common in syntax, but they are very common in morphology. For example, a compound may be reinterpreted as an affixoid plus a host, after which the affixoid becomes productive and possibly turns into an affix or, through debonding, into an adjective (de Vries 1920-1922, Booij 2010, Van Goethem \& Hüning 2015, inter alia).

All the English and Dutch degree resultatives we have come across have a corresponding literal resultative - as expected under our analysis. However, as an anonymous referee pointed out, German appears to have degree resultative constructions entirely parallel to Dutch type $4 \mathrm{~b}$ that lack literal counterparts (Oppenrieder 1991, Wunderlich 1997, Müller 2002:216), as in Müller's (2002) example Er freute sich dumm und dusselig über das Buch 'He was pleased as punch about the book' lit. 'He pleased himself stupid and daft over the book'. Degree resultatives could have gone through a spurt of popularity in German starting in the mid-1800s, as they did in English and Dutch. In this case, the rapid proliferation of degree interpretations could have led to experimentation with new verbs and secondary predicates, which could not occur in ordinary, first-order resultatives. While we have not examined the history of degree resultatives in German, Dutch type $4 \mathrm{~b}$ first occurs in Delpher in the 1860 s - which would give some plausibility to our hypothesis if German historical patterns are comparable to the Dutch ones.

We presented a number of case studies (for both English and Dutch) in which we compare the verbs that associate with a given predicate. Some of the resultative predicates studied here combine with a narrowly circumscribed and semantically coherent set of verbs, while others engage 
in a variety of combinations in which the verbs show little or no semantic coherence, apart from gradability. In that sense, resultative predicates resemble degree adverbs, some of which select a small semantically coherent group of modified elements (adjectives or verbs), while others combine with a broader range of items (see Hoeksema 2005).

We have noted that the transitivity status of the verb whose meaning is intensified determines whether fake reflexives and subject-oriented possessives are used. While English and Dutch are mostly alike in this regard, there is one main difference: Dutch has a large class of inherently reflexive verbs. Such verbs are syntactically transitive, but semantically intransitive in the sense that their object does not have a theta role.

Using large diachronic corpora (COHA and Delpher), we traced degree resultative constructions in English and Dutch over a period of two centuries (1800-2000), during which they grow considerably, both in token frequency and in type diversity. In many of these changes, English seems to be leading, and Dutch following at a close distance. At the same time, Dutch shows a few innovative traits of its own, such as the use of disease names in degree resultatives. This ties in with the more general proclivity of Dutch swear expressions to employ names of contagious diseases (see Nübling \& Vogel 2004). In this respect, Dutch differs not only from English, but also from German and the northern Germanic languages.

While in both English and Dutch some degree resultatives are attested as early as the 17th century, it is not until the period studied here that they become an important feature of the two languages, especially in the more informal registers. At the same time, one sees a rapid increase in taboo terms in these degree resultatives, primarily from the domains of religion, death, excretions, and sex. In this respect, degree resultatives resemble adverbs of degree and minimizing polarity items, which show similar developments (Napoli \& Hoeksema 2009). In all such uses, taboo terms have a strengthening, not a mitigating effect. It remains to be seen to what extent languages outside of the West-European group have degree resultatives. The literature on resultatives is vast, but on the topic of degree resultatives there is still much to be done. 


\section{APPENDIX}

Resultative predicates per period of first occurrence in our data:

\section{ENGLISH}

1800-1850

black and blue

half to death

hollow

one's eyes out

one's fingers to the bone

one's heart out

one's little heart out

out of one's senses

out of one's wits

\section{0-1900}

black and blue in the face

black in the face

blue

crazy

half blind

into a pulp

into oblivion

one's guts out

one's head off

one's legs off

\section{0-1950}

batty

blue in the face

clean to death

into a stupor

limp

one's arms and legs off

one's ass/arse off

one's ears off

one's fool head off

one's little head off

one's lungs out

one's tail off

out of one's skin

ragged

silly sick

someone's brains out

stupid

the devil out of

to a shadow

to death

to death and distraction

to ribbons

rotten

stiff

the daylights out of

the legs off an iron pot

the life out of

the stuffing out of

the wits out of

to bits

to pieces

to the bone

someone's ass off

the bejesus out of

the deuce out of

the hell out of

the legs off

the living daylights out of

the living hell out of

the living tar out of

the pants off

the piss out of

the shirt off one's back

the shit out of

the tar out of

witless 
1950-2000

into a tizzy

one's balls off

one's behind off

one's bum off

one's buns off

one's butt off

one's fucking head off

one's nuts off

one's pretty little ass off

one's rear end off

one's smart little ass off

one's socks off

out of one's mind

out of one's skull

\section{DUTCH}

\section{0-1850}

blind 'blind'

de huid vol 'the skin full'

een ongeluk 'an accident'

een stuk in de kraag

'a piece in the collar'

\section{0-1900}

blauw 'blue'

bont en blauw 'colorful and blue'

de handen stuk 'the hands broken'

de kelen schor/hun kelen schor 'the(ir)

throats hoarse'

de longen uit het/zijn lijf 'the lungs

from the/his body'

de ogen uit zijn hoofd 'the eyes out of

the head'

de vingers lam 'the/his fingers lame'

delzijn vingers blauw 'the/his fingers

blue'

dood 'dead'

een beroerte 'a stroke'

een bochel 'a hunchback' out of one's socks

senseless

shitless

someone's ass off

the blood out of

the crap out of

the dickens out of

the fuck out of

the heck out of

the hind legs off a donkey

the living crap out of

the living piss out of

the living shit out of

the snot out of

gek 'crazy'

het hemd van het lijf

'the shirt off the body'

lam 'lame'

suf 'drowsy, stupid'

een breuk 'a hernia'

een bult 'a hunchback/bump'

half mal 'half-mad'

halfdood 'half-dead'

het vuur uit de/zijn sloffen 'the fire

from the/his slippers'

kapot 'kaput/broken'

krom 'bent'

slap 'weak'

te barsten 'to (the point of) bursting'

tot moes 'to (a) pulp' 


\section{0-1950}

blauw en groen 'blue and green' de benen uit het lijf 'the legs out of the body' de blubber 'the mud' de keel/kelen hees/zijn keel hees 'the/his throat hoarse'

de/zijn ogen uit de kop 'the/his eyes out of the head'

de oren van de kop 'the ears off the head' de oren van het hoofd 'the ears off the head'

de rambam (see note 11)

de tering 'the tuberculosis'

een aap 'a monkey' een hoedje 'a little hat' een kriek 'a cherry' een puist 'a pimple' een rotje 'a firecracker' (wordplay on rot 'rotten') groen en geel 'green and yellow'

\section{0-2000}

aan gort 'to barley'

de ballen uit de/zijn broek 'the balls out of the/his pants'

de blaren op de/zijn tong 'the blisters on the/his tongue'

de broek van het lijf' the pants off the body' de broek van zijn reet 'the pants off the ass'

de hemel in 'into the sky/heaven' de klere 'the cholera' de pannen van het dak 'the tiles off the roof' de pestpleuris 'the pest-pleurisy' de pleuris 'the pleurisy' de poten uit het/zijn lijf 'the legs out of the/his body' half gek 'half mad'

het ape(n)zuur 'the monkey acid' het bloed onder de nagels vandaan 'the blood from under the nails' in elkaar 'in each other=to shambles' in puin 'in rubble'

lamme vingers 'lame fingers' naar 'nasty, sick' ongans 'unwell, nauseous' rot 'rotten' scheef 'crooked, slanted' scheel 'cross-eyed' uit de naad 'out of the stitch' verrot 'rotten' wezenloos 'mindless' wild 'wild'

de tyfus 'the typhus' een deuk 'a dent' een hartverzakking 'a heart attack' een rolberoerte 'a seizure' een slag in de rondte 'a punch in the round' het apelazerus 'the monkey leprosy' het leplazerus 'the lep-leprosy' (wordplay with unclear meaning' het schompes 'the schompes' (word of unknown origin) het snot voor de ogen 'the snot before the eyes' $n$ slagen in de rondte " $n$ punches in the round' te pletter 'to smithereens' 


\section{REFERENCES}

Baker, Mark. 1989. Object sharing and projection in serial verb constructions. Linguistic Inquiry 20. 513-553.

Bentley, Delia. 2017. 9 copular and existential constructions. Manual of Romance morphosyntax and syntax, vol. 17, ed. by Andreas Dufter \& Elisabeth Stark, 332-366. Berlin: De Gruyter.

Bolinger, Dwight L. 1972. Degree words. The Hague: Mouton.

Booij, Geert E. 2010. Construction morphology. Oxford: Oxford University Press.

Bouma, Gosse, \& Jennifer Spenader. 2008. The distribution of weak and strong object reflexives in Dutch. LOT Occasional Series 12. 103-114.

Bouma, Harlynn. 2016. Op mijn lijf geschreven: Verandering in het gebruik van lidwoorden en bezittelijke voornaamwoorden in een klasse van Nederlandse idiomen. Groningen, The Netherlands: University of Groningen undergraduate thesis.

Braver, Aaron, Natalie Dresher, \& Shigeto Kawahara. 2016. The phonetics of emphatic vowel lengthening in English. Supplemental Proceedings of the 2014 Annual Meeting on Phonology, ed. by Adam Albright \& Michelle A. Fullwood. Available at doi.org/10.3765/amp.v2i0.3754, accessed on May 29, 2018.

Brito, Lucinda Ferreira. 1984. Similarities \& differences in two Brazilian sign languages. Sign Language Studies 42. 45-56.

Broekhuis, Hans, Norbert Corver, \& Riet Vos. 2015. Syntax of Dutch: Verbs and verb phrases, vol. 1. Amsterdam: Amsterdam University Press.

Cappelle, Bert. 2007. When 'wee wretched words' wield weight: The impact of verbal particles on transitivity. Proceedings of the First Nordic Conference on Syntactic Freezes, Joensuu, Finland, 19-20 May 2006, ed. by Marja Nenonen \& Sinikka Niemi, 41-54. Joensuu: University of Joensuu.

Cappelle, Bert. 2014. Conventional combinations in pockets of productivity: English resultatives and Dutch ditransitives expressing excess. Extending the scope of construction grammar, ed. by Ronny Boogaart, Timothy Colleman, \& Gijsbert Rutten, 251-282. Amsterdam: John Benjamins.

Carrier, Jill, \& Janet H. Randall. 1992. The argument structure and syntactic structure of resultatives. Linguistic Inquiry 23. 173-234.

Chappell, Hilary, \& William McGregor. 1996. The grammar of inalienability: A typological perspective on body part terms and the part-whole relation. Berlin: Walter de Gruyter.

Cheng, Lisa Lai-Shen, \& C.-T. James Huang. 1995. On the argument structure of resultative compounds. In honor of William Wang: Interdisciplinary studies on language and language change, ed. by Matthew Chen \& Ovid Tzeng, 187221. Taipei: Pyramid Press.

Collins, Chris, Simanique Moody, \& Paul Postal. 2008. An AAE camouflage construction. Language 84. 29-68. 
Corver, Norbert. 1997. The internal syntax of the Dutch extended adjectival projection. Natural Language and Linguistic Theory 15. 289-368.

Culicover, Peter W., \& Ray Jackendoff. 2005. Simpler syntax. Oxford: Oxford University Press.

Davies, Mark. 2012. The 400 million word corpus of historical American English (1810-2009). English Historical Linguistics 2010, ed. by Irén Hegedus \& Alexandra Fodor, 217-250. Amsterdam: John Benjamins.

Diewald, Gabriele. 2002. A model for relevant types of contexts in grammaticalization. New reflections on grammaticalization, ed. by Ilse Wischer \& Gabriele Diewald, 103-120. Amsterdam: John Benjamins.

Dikken, Marcel den. 1995. Particles: On the syntax of verb-particle, triadic, and causative constructions. Oxford: Oxford University Press.

Dowty, David R. 1979. Word meaning and Montague grammar: The semantics of verbs and times in generative semantics and in Montague's PTQ. Dordrecht: D. Reidel.

Dressler, Wolfgang U., \& Lavinia Merlini Barbaresi. 1994. Morphopragmatics: Diminutives and intensifiers in Italian, German, and other languages. Berlin: Walter de Gruyter.

Endt, Enno, \& Lieneke Frerichs. 1986. Bargoens woordenboek. Amsterdam: Bert Bakker.

Everaert, Martin. 1986. The syntax of reflexivization. Dordrecht: Foris.

Farkas, Imola-Ágnes. 2009. Some differences between English and Romanian resultative constructions. Bucharest Working Papers in Linguistics 2. 59-71.

Farkas, Imola-Ágnes. 2011. Resultative expressions in Romanian. Ianua. Revista Philologica Romanica 11. 67-88.

Fernández Leborans, Jesús 1999. La predicación: las oraciones copulativas, Gramática descriptiva de la lengua española, ed. by Ignacio Bosque \& Violete Demonte, 2358-2460. Madrid: Espasa.

Giannakidou, Anastasia, \& Jason Merchant. 1999. Why Giannis can’t scrub his plate clean: On the absence of resultative secondary predication in Greek. Greek Linguistics '97: Proceedings of the Third International Conference on Greek Linguistics, ed. by Amalia Mozer, 93-103. Athens: Ellinika Grammata.

Givón, Talmy. 1991. The evolution of dependent clause morpho-syntax in Biblical Hebrew. Approaches to grammaticalization, vol. II: Types of grammatical markers, ed. by Elizabeth Closs Traugott \& Bernd Heine, 257310. Amsterdam: John Benjamins.

Goldberg, Adele E. 1995. Constructions. A construction grammar approach to argument structure. Chicago, IL: The University of Chicago Press.

Goldberg, Adele E. 1997. Making one's way through the data. Complex predicates, ed. by Alex Alsina, Joan Bresnan, \& Peter Sells, 151-173. Stanford, CA: CSLI Publications. 
Goldberg, Adele, \& Ray Jackendoff. 2004. The English resultative as a family of constructions. Language 80. 532-568.

Gordon, Lynn. 1986. Maricopa morphology and syntax. Berkeley, CA: University of California Press.

Gyselinck, Emmeline. 2018. The role of expressivity and productivity in (re)shaping the constructional network. A corpus-based study into synchronic and diachronic variation in the intensifying fake reflexive resultative construction in 19th to 21st Century Dutch. Ghent, Belgium: Universiteit Gent dissertation.

Gyselinck, Emmeline, \& Timothy Colleman. 2016a. Je dood vervelen of je te pletter amuseren? Het intensiverende gebruik van de pseudoreflexieve resultatiefconstructie in hedendaags Belgisch en Nederlands Nederlands. Handelingen van de Koninklijke Zuid-Nederlandse Maatschappij voor Taalen Letterkunde en Geschiedenis 69. 103-136.

Gyselinck, Emmeline, \& Timothy Colleman. 2016b. Tracking shifts in the literal versus the intensifying fake reflexive resultative construction. The development of intensifying dood 'dead' in 19th-20th Century Dutch. Belgian Journal of Linguistics 30. 55 -90.

Haik, Isabelle. 2012. The hell in English grammar. Relations, connexions, dépendances: Homage au professeur Claude Guimier, ed. by Nicole le Querler, Franck Neveu, \& Emmanuelle Roussel, 101-126. Rennes: Presses Universitaires de Rennes.

Hale, Ken, \& Samuel Jay Keyser. 1996. On the double-object construction. Unpublished manuscript, MIT. Available at http://citeseerx.ist.psu.edu/viewdoc/ download?doi=10.1.1.3.8225\&rep=rep1\&type=pdf, accessed on January 27, 2018.

Harley, Heidi. 2002. Possession and the double object construction. Linguistic Variation Yearbook 2. 31-70.

Haspelmath, Martin. 2001. The European linguistic area: Standard average European. Language typology and language universals, ed. by Martin Haspelmath, Ekkehard König, Wulf Oesterreicher, \& Wolfgang Raible, 14921510. Berlin: De Gruyter.

Heine, Bernd, \& Tania Kuteva. 2006. The changing languages of Europe. Oxford: Oxford University Press.

Heinsius, Jacobus. 1929. Over verbindingen als tot barstens toe. Tijdschrift voor Nederlandse Taal- en Letterkunde 48. 237-240.

Hendriks, Petra, John C. J. Hoeks, \& Jennifer Spenader. 2014. Reflexive choice in Dutch and German. The Journal of Comparative Germanic Linguistics 17. 229-252.

Herschensohn, Julia. 1992. French inalienable binding. Theoretical analyses in Romance linguistics: Selected papers from the Linguistic Symposium on 
Romance Languages XIX, ed. by Christiane Laeufer \& Terrell Morgan, 367384. Amsterdam: John Benjamins.

Hoeksema, Jack. 2001. Rapid change among expletive polarity items. Historical linguistics 1999: Selected papers from the Fourteenth International Conference on Historical Linguistics, ed. by Laurel J. Brinton, 175-186. Amsterdam: John Benjamins.

Hoeksema, Jack. 2005. Rijkdom en weelde van het Nederlands. Tabu 34. 1-12.

Hoeksema, Jack. 2012. Elative compounds in Dutch: Types and historical development. Crosslinguistic comparison of intensified adjectives and adverbs, vol. 2, ed. by Guido Oebel, 97-142. Hamburg: Verlag Dr. Kovač.

Hoeksema, Jack, \& Donna Jo Napoli. 2008. Just for the hell of it: A comparison of two taboo-term constructions. Journal of Linguistics 44. 347-378.

Hoekstra, Teun, \& René Mulder. 1990. Unergatives as copular verbs: Locational and existential predication. The Linguistic Review 7. 1-79.

Hoekstra, Teun. 1984. Transitivity: Grammatical relations in governmentbinding theory. Dordrecht: Foris.

Hoekstra, Teun. 1988. Small clause results. Lingua 74. 101-139.

Hoekstra, Teun, Monic Lansu, \& Marion Westerduin. 1987. Complexe verba. Glot 10. 61-78.

Hout, Angeliek van. 2012. Event semantics of verb frame alternations: A case study of Dutch and its acquisition. London: Routledge.

Irwin, Patricia. 2015. Expressive meaning in an AAE attributive construction. Language Sciences 50. 12-29.

Israel, Michael. 1996. The way constructions grow. Conceptual structure, discourse and language, ed. by Adele E. Goldberg, 217-230. Stanford, CA: CSLI Publications.

Jackendoff, Ray S. 1992. Babe Ruth homered his way into the hearts of America. Stowell \& Wehrli, 155-178.

Kayne, Richard S. 1985. Principles of particle constructions. Grammatical representation, ed. by Jacqueline Guéron, Hans-Georg Obenauer, \& JeanYves Pollock, 101-140. Dordrecht: Foris.

Kennedy, Christopher, \& Louise McNally. 2005. Scale structure, degree modification, and the semantics of gradable predicates. Language 81. 345-381.

Kentner, Ashley. 2014. Event structure of resultatives in ASL. West Lafayette, IN: Purdue University MA thesis.

Keyser, Samuel Jay, \& Thomas Roeper. 1992. Re: The abstract clitic hypothesis. Linguistic Inquiry 23. 89-126.

Kim, Jong-Bok. 1993. Syntax and semantics of Korean resultative constructions. Harvard studies in Korean linguistics V, ed. by Susumu Kuno, Ik-Hwan Lee, John Whitman, Joan Maling, Young-Se Kang, \& Young-Joo Kim, 471-482. Cambridge, MA: Department of Linguistics, Harvard University. 
Klein, Henny. 1998. Adverbs of degree in Dutch and related languages. Amsterdam: John Benjamins.

Kratzer, Angelika. 2005. Building resultatives. Event arguments: Foundations and applications, ed. by Claudia Maienborn \& Angelika Wöllstein, 177-212. Tübingen: Max Niemeyer Verlag.

Larson, Richard K. 1988. On the double object construction. Linguistic Inquiry 19. 335-331.

Leeson, Lorraine, \& John I. Saeed. 2012. Irish Sign Language: A cognitive linguistic account. Edinburgh: Edinburgh University Press.

Legendre, Géraldine. 1997. Secondary predication and functional projections in French. Natural Language and Linguistic Theory 15. 43-87.

Levin, Beth. 1993. English verb classes and alternations: A preliminary investigation. Chicago, IL: University of Chicago Press.

Levin, Beth, \& Malka Rappaport Hovav. 1991. Wiping the slate clean: A lexical semantic exploration. Cognition 41: Special issue on lexical and conceptual semantics, ed. by Beth Levin \& Steven Pinker, 123-151.

Li, Yafei. 1995. The thematic hierarchy and causativity. Natural Language and Linguistic Theory 13. 255-282.

Lødrup, Helge. 1999. Inalienables in Norwegian and binding theory. Linguistics 37. 365-388.

Loos, Cornelia. 2017. The syntax and semantics of resultative constructions in Deutsche Gebärdensprache (DGS) and American Sign Language (ASL). Austin, TX: University of Texas dissertation.

Marantz, Alec. 1992. The way-construction and the semantics of direct arguments in English: A reply to Jackendoff. Stowell \& Wehrli 1992, 179-188.

Margerie, Hélène. 2011. Grammaticalising constructions: To death as a peripheral degree modifier. Folia Linguistica Historica 32. 115-148.

Matsui, Natsuki. 2007. Classification of Thai resultatives: Serial verb and other similar constructions. 人文論究 56. 93-110.

Mirus, Gene, Jami Fisher, \& Donna Jo Napoli. 2012. Taboo expressions in American Sign Language. Lingua 122. 1004-1020.

Mondorf, Britta. 2011. Variation and change in English resultative constructions. Language Variation and Change 22. 397-421.

Müller, Stefan. 2002. Complex predicates: Verbal complexes, resultative constructions, and particle verbs in German. Stanford, CA: CSLI Publications.

Napoli, Donna Jo. 1992. Secondary resultative predicates in Italian. Journal of Linguistics 28. 53-90.

Napoli, Donna Jo, \& Jack Hoeksema. 2009. The grammatical versatility of taboo terms. Studies in Language 33. 612-643.

Neeleman, Ad, Hans van de Koot, \& Jenny Doetjes. 2004. Degree expressions. The Linguistic Review 21. 1-66. 
Neeleman, Ad, \& Fred Weerman. 1993. The balance between syntax and morphology: Dutch particles and resultatives. Natural Language and Linguistic Theory 11. 433-475.

Nishiyama, Kunio. 1998. V-V compounds as serialization. Journal of East Asian Linguistics 7. 175-217.

Nübling, Damaris, \& Marianne Vogel. 2004. Fluchen und schimpfen kontrastiv. Zur sexuellen, krankheitsbasierten, skatologischen und religiösen Fluch- und Schimpfwortprototypik im Niederländischen, Deutschen und Schwedischen. Germanistische Mitteilungen 59. 19-33.

Odijk, Jan, Gertjan van Noord, Peter Kleiweg, \& Erik Tjong Kim Sang. 2017. The Parse and Query (PaQu) Application. CLARIN in the Low Countries, ed. by Jan Odijk \& Arjan van Hessen, 281-297. London: Ubiquity Press. License: CC-BY 4.0

Oppenrieder, Wilhelm. 1991. Von Subjekten, Sätzen und Subjektsätzen (Linguisitische Arbeiten 241). Tübingen: Max Niemeyer Verlag.

Paradis, Carita. 2001. Adjectives and boundedness. Cognitive Linguistics 12. 47-65.

Perek, Florent. 2016. Using distributional semantics to study syntactic productivity in diachrony: A case study. Linguistics 54. 149-188.

Polanyi, Livia. 1985. Conversational storytelling. Handbook of discourse analysis: Discourse analysis in society, ed. by Teun van Dijk, 183-201. New York, NY: Academic Press.

Postma, Gertjan. 1997. Logical entailment and the possessive nature of reflexive pronouns. Atomism and binding, ed. by Hans Bennis, Pierre Pica, \& Johan Rooryck, 295-322. Dordrecht: Foris.

Reinhart, Tanya, \& Eric Reuland. 1993. Reflexivity. Linguistic Inquiry 24. $657-$ 720.

Romaine, Suzanne. 1999. Communicating gender. Mahwah, NJ: Lawrence Erlbaum.

Rooryck, Johan. 2017. Reconsidering inalienable possession in French. Unpublished manuscript, Leiden University. Available at https://docs.wixstatic. com/ugd/d58ca7_3cba655109ab4828ab967ffc3287a4c9.pdf, accessed on May 28, 2018.

Rotstein, Carmen, \& Yoad Winter. 2004. Total adjectives vs. partial adjectives: Scale structure and higher-order modifiers. Natural Language Semantics 21. 259-288.

Sandig, Barbara. 1991. Formeln des Bewertens. Europhras 90, ed. by Christine Palm, 252-252. Stockholm: Almqvist \& Wiksell.

Sapir, Edward. 1944. Grading, a study in semantics. Language 11. 93-116.

Sells, Peter. 1987. Aspects of logophoricity. Linguistic Inquiry 18. 445-479.

Sijs, Nicoline van der. 2001. Chronologisch woordenboek. De ouderdom en herkomst van onze woorden en betekenissen. Amsterdam: L.J. Veen. 
Simpson, Jane. 1983. Resultatives. Papers in lexical functional grammar, ed. by Lori Levin, Malka Rappaport, \& Annie Zaenen, 143-157. Bloomington, IN: Indiana University Linguistics Club.

Snyder, William. 2001. On the nature of syntactic variation: Evidence from complex predicates and complex word-formation. Language 77. 324-342.

Snyder, William, \& Karin Stromswold. 1997. The structure and acquisition of English dative constructions. Linguistic Inquiry 28. 281-317.

Stassen, Leon. 1985. Comparison and universal grammar. Oxford: Blackwell.

Stiebels, Barbara. 1998. Complex denominal verbs in German and the morphology-semantics interface. Yearbook of Morphology 1997. 265-302.

Stowell, Timothy, \& Eric Wehrli (eds.). 1992. Syntax and semantics: Syntax and the lexicon 26. New York, NY: Academic Press.

Sutton-Spence, Rachel, \& Donna Jo Napoli. 2013. How much can classifiers be analogous to their referents? Gesture 13. 1-27.

Sybesma, Rint. 1992. Causatives and accomplishments: The case of Chinese BA. Leiden, the Netherlands: Leiden University dissertation.

Tang, Gladys, \& Gu Yang. 2007. Events of motion and causation in Hong Kong Sign Language. Lingua 117. 1216-1257.

Thompson, Sandra A. 1973. Resultative verb compounds in Mandarin Chinese: A case for lexical rules. Language 49. 361-379.

Traugott, Elizabeth Closs, \& Graeme Trousdale. 2013. Constructionalization and constructional changes. Oxford: Oxford University Press.

Trawiński, Beata, Manfred Sailer, Frank Richter, \& Lothar Lemnitzer. 2008. Cranberry expressions in English and in German. Proceedings of the LREC Workshop Towards a Shared Task for Multiword Expressions (MWE 2008), ed. by Nicole Grégoire, Stefan Evert, \& Brigitte Krenn, 35-38. Marrakech: LREC.

Tribushinina, Elena, \& Theo Janssen. 2011. Re-conceptualizing scale boundaries: The case of Dutch helemaal. Journal of Pragmatics 43. 2043-2056.

Van Goethem, Kristel, \& Matthias Hüning. 2015. From noun to evaluative adjective: Conversion or debonding? Dutch top and its equivalents in German. Journal of Germanic Linguistics 27. 366-409.

Verhagen, Arie. 2003. The Dutch way. Usage-based approaches to Dutch, ed. by Arie Verhagen \& Jeroen van de Weijer, 27-57. Utrecht: LOT.

Vries, Wobbe de. 1920-1922. Iets over woordvorming. Groningen: Municipal Gymnasium.

Walková, Milada. 2017. Particle verbs in English: Telicity or scalarity? Linguistics 55. 589-616.

Washio, Ryuichi. 1997. Resultatives, compositionality and language variation. East Asian Journal of Linguistics 6. 1-49.

Wechsler, Stephen. 2005. Resultatives under the "event-argument homomorphism" model of telicity. The syntax of aspect: Deriving thematic 
and aspectual information, ed. by Nomi Erteschik-Shir \& Tova Rapoport, 255-273. Oxford: Oxford University Press.

Wechsler, Stephen, \& Bokyung Noh. 2001. On resultative predicates and clauses: Parallels between Korean and English. Language Sciences 23. 391-423.

Wilcox, Sherman, \& Barbara Shaffer. 2006. Modality in American Sign Language. The expression of modality, ed. by William Frawley, 207-237. Berlin: Mouton de Gruyter.

Wilcox, Sherman, Phyllis Perrin Wilcox, \& Maria Josep Jarque. 2003. Mappings in conceptual space: Metonymy, metaphor, and iconicity in two signed languages. Jezikoslovlje 4. 139-156.

Wunderlich, Dieter. 1997. Argument extension by lexical adjunction. Journal of Semantics 14. 95-142.

Zillig, Werner. 1982. Bewerten: Sprechakttypen der bewertenden Rede. Berlin: Walter de Gruyter.

\section{DATA SOURCES}

Corpus of Historical American English. Available at https://corpus.byu.edu/coha/. Corpus of American Soap Operas. Available at https://corpus.byu.edu/soap/.

De Gooi- en Eemlander (Dutch daily newspaper).

Delpher. Available at www.delpher.nl.

Gaia (online subscription service). Available at https://www.gaia.com/article/ native-american-creation-myths-uncovered-explained, accessed on April 2, 2018.

Good Relaxation (online resource). Available at www.goodrelaxation.com, accessed on April 2, 2018.

Lassy Groot-corpus. Available at https://ivdnt.org/taalmaterialen/102taalmaterialen/ 2056-tstc-lassy-groot-corpus, accessed on February 4, 2019.

LexisNexis. Available at http://academic.lexisnexis.nl/, accessed on February 4, 2019.

Libelle (Dutch language weekly women's magazine).

Michael Smith News. 2015. Christine Milne to ISIS-when recreational beheadings beckons, try social cohesion instead. Available at http://www.michaelsmithnews.com/2015/02/christine-milne-to-isis-whenrecreational-beheading-beckons-try-social-cohesion-instead.html, accessed on December 16, 2015.

NRC Handelsblad (daily newspaper). Available at https://www.nrc.nl/.

Perry, Eleanor. 1968. The swimmer. Screenplay.

PowNeD (Dutch radio and TV broadcaster). Available at www.powned.tv, accessed on February 3, 2019. 
Talentwerk (website by Ria Freijsen). Available at https://www.talentwerk.nl/ waarom-doe-ik-niet-wat-ik-wil-en-omgekeerd/, accessed on January 31, 2019.

The Independent. Available at https://www.independent.co.uk/arts-entertainment /interview-jeff-goldblum-youve-got-to-hand-it-to-him-theres-more-thanchaos-theory-at-work-in-jeff-1486363.html, accessed on January 31, 2019.

Wodehouse, P.G. 1961 [1936]. Laughing gas. London: Penguin.

WNT (Wordenboek der Nederlandsche Taal [Dictionary of the Dutch language]). Available at https://ivdnt.org/onderzoek-a-onderwijs/lexicologiea-lexicografie/wnt.

Zimmer, Ben. 2016. I agreed the fuck out of it. Strong Language (online blog). Available at https://stronglang.wordpress.com/2016/02/11/i-agreed-the-fuckout-of-it/\#more-3420, accessed on January 31, 2019.

\section{Jack Hoeksema}

Department of Dutch Language and Culture

University of Groningen

P.O. Box 716

9700 AS Groningen

The Netherlands

[j.hoeksema@rug.nl]

Donna Jo Napoli

Department of Linguistics

Swarthmore College

Swarthmore, PA 19081

USA

[dnapoli1@swarthmore.edu] 